\title{
O GOVERNO DE SERGIPE E A LEI DE RESPONSABILIDADE FISCAL
}

\section{Resumo}

O presente trabalho pretendeu verificar os impactos da Lei Complementar n. ${ }^{\circ}$ 101/2000, a chamada Lei de Responsabilidade Fiscal (LRF) sobre a condição fiscal do Estado de Sergipe. No artigo avaliou - se o comportamento de alguns indicadores escolhidos como o montante de investimento, em face do volume de operações de crédito contratadas, o comportamento da Receita Corrente Líquida (RCL) conduzido pelo modesto crescimento do FPE, que é seu carro chefe, em relação a um melhor desempenho do ICMS; bem como a evolução da Despesa Corrente Líquida- DCL.

Palavras-chave: Lei de Responsabilidade Fiscal - LRF; Gasto público. Dívida.

Abstract: This study aimed to verify the impacts of Complementary Law n. ${ }^{\circ} 101 / 2000$, the so-called Fiscal Responsibility Law (FRL) on the fiscal condition of the state of Sergipe.. We also assessed the behavior of some indicators chosen as the amount of investment, given the volume of contracted loans, the behavior of the current revenue settlement RCL conducted by the modest growth of the PEF, which is its flagship, in relation to a best performance of the ICMS; as well as the evolution of Current Expenditure settlement DCL.

Keywords: Law of Fiscal Responsibility-FRL. Public spending. Debt.

\section{Introdução}

A análise pretendida com este artigo considerou os indicadores previstos na Lei de Responsabilidade Fiscal para o Estado de Sergipe de 2001 a 2013. O Estado obteve forte incentivo estatal federal na década de 80 , com um considerado crescimento econômico, e na década seguinte se iguala ao contexto nacional de endividamento. A adesão de Sergipe ao Programa de Apoio à Reestruturação e ao Ajuste Fiscal de Estados permitiu uma transição tranquila para obediência às regras da LRF. Os números apresentados pelo Estado no que se referem às receitas, despesas, encargos de dívidas, operações de crédito revelam que o crescimento das principais receitas estaduais não tem acompanhado a evolução das dívidas, e assim verificou-se o endividamento especialmente a partir do ano de 2009, e após 2011, o Estado não obteve uma classificação da capacidade de pagamento adequada para suportar seus compromissos, necessitando de manifestação favorável do Secretário da Secretaria do Tesouro Nacional, ou seja, apoio político e não pronunciamento técnico.

\footnotetext{
${ }^{1}$ Professor Titular DEE - UFS. Doutor em Ciências - Economia Aplicada - Universidade de São Paulo - USP.

${ }^{2}$ Graduação em Economia - UFS. Mestrado em Economia - UFS. 
A estrutura proposta para o trabalho é feita em sete seções. Inicialmente a introdução; já na segunda seção será apresentada a literatura teórica que dá suporte às Finanças Públicas através das quatro questões básicas, além de passar pelas funções econômicas do Estado; na terceira seção será feita uma exposição acerca da literatura empírica sobre a Lei de Responsabilidade Fiscal e os seus indicadores; na seção seguinte, a quarta, apresenta-se a metodologia. Na seção cinco se pretende fazer uma explanação sobre o cenário existente no Brasil que engloba os antecedentes da Lei de Responsabilidade Fiscal, a Lei de Responsabilidade Fiscal em si, com seus princípios, regras e indicadores; o destaque para o procedimento de contratação de operações de crédito, a capacidade de pagamento, e uma passagem pela economia do Brasil de 2001 a 2013. Na sexta seção, procura-se fazer um panorama sobre Sergipe, passando pelo cenário econômico e adentrando nas finanças públicas para mostrar o comportamento das principais receitas, a evolução da dívida consolidada; dívida consolidada líquida, dívida contratual interna e externa, o desempenho das operações de crédito, investimentos, inversões financeiras, despesas de correntes, pessoal e encargos sociais. Também se avalia o comportamento do PIB em Sergipe e os números apresentados por Sergipe para os indicadores da LRF. Finalmente tem-se a considerações finais.

\section{Literatura empírica.}

Desde a implantação da LRF, o impacto de seus efeitos sobre os entes federados tem sido objeto de diversos estudos pela literatura empírica brasileira.

O trabalho de Mendes (2009) avalia o crescimento econômico dos estados do Nordeste entre 2001 e 2008. Neste período, o crescimento da região nordeste oscila entre $2,57 \%$ e $5,27 \%$ mais que a média nacional que foi de 2,28\%. O gasto com pessoal é uma das variáveis independentes analisadas, constatando-se que todos os estados da região atingiram limite inferior aos 49\% da Receita Corrente Líquida (RCL) fixada para o Poder Executivo. Giuberti (2005) também examina se os gastos com pessoal dos municípios brasileiros precisavam ser reprimidos pela instituição de uma regra, no período de 1997 a 2003; e embora sem obter dados para todos os municípios no intervalo em estudo, assevera que para a média dos Municípios, independente do tamanho deste, a LRF não influiu na conduta dos gestores públicos. Na análise individual dos municípios, em 1997, 11,4\% destes empregavam mais de $60 \%$ da sua receita corrente líquida com o pagamento de servidores e encargos; enquanto que em 2003, a porcentagem diminui para 0,9\% dos municípios. Já Jayme Jr, Romero e Reis 
(2006) avaliando a situação das Finanças Públicas do estado de Minas Gerais no período de 1995-2005, constata o crescimento de $80 \%$ dos gastos com pessoal e encargos, no lapso temporal.

O mesmo Jayme Jr, Romero e Reis (2006) argumenta que a assinatura em 1998 do acordo de renegociação de dívida com base no Programa de Reestruturação e Ajuste Fiscal (Lei 9496/1997) trouxe efeitos negativos para as finanças de MG, devido à elevação do estoque da dívida (juros e encargos) por conta da incorporação do saneamento de bancos estaduais e de que os valores acordados não foram suficientes para pagamento dos encargos da nova dívida. Giuberti (2005) não observa uma realidade de endividamento excessivo para a maioria dos municípios brasileiros. Ao contrário, a porcentagem de municípios com déficit corrente, que era reduzida em 1997 (24,5\%), alterou-se para 1,4\% em 2003. A autora comenta que o endividamento excessivo alcança poucos municípios com população que excede a um milhão de habitantes. E nesse caso, o montante da dívida representa $80 \%$ da dívida de todos os municípios avaliados no estudo.

Em relação às operações de crédito internas e externas em relação a receita corrente líquida (RCL), Mendes (2009) informa que a média da região foi de 1,84\%, com o maior percentual para o Ceará com 5,05\%; o segundo maior Bahia com 3,90\%. O menor percentual foi para o Rio Grande do Norte, com 0,76\%. Sergipe obteve 1,26\%. A região nordeste está abaixo do parâmetro de 16\% da RCL. Diversamente do previsto na LRF, Jayme Jr, Romero e Reis (2006), tratou das receitas de operações de crédito em cotejo com as despesas de capital, no que chamou de indicador de gestão fiscal [(IGF3) = Receita de Operação de Crédito/Despesa de Capital], informando que houve declínio ao longo do período por conta da limitação da LRF em relação às operações de crédito. Continua acrescentando que com isso as despesas de capital captaram mais recursos oriundos da receita corrente, afetando as finanças estaduais de Minas Gerais por reduzir a receita corrente líquida do Estado.

Em relação à razão Dívida Líquida Consolidada/Receita Corrente Líquida para o Estado de Minas Gerais e tratada por Jayme Jr, Romero e Reis (2006), como indicador de gestão fiscal (IGF2), o Estado esteve numa situação considerada critica por iniciar o período acima do teto e no final estar muito próximo do teto, que é 2. A região Nordeste retratada por Mendes (2009) esteve numa situação mais confortável, já que este indicador oscilou entre 0,3911 e 1,531; exceto para o estado de Alagoas que atingiu 2,28. Sergipe atingiu 0,5628. 
Jayme Jr, Romero e Reis (2006) analisou cinco indicadores de Estrutura financeira investigando as seguintes relações: (IEF1) (receita tributária+ transferências constitucionais) /Receita Corrente Líquida; (IEF2) Receita Tributária Própria/Receita Disponível; (IEF3) Despesa com Pessoal/Receita Disponível; (IEF4) Encargos da Dívida/Receita Disponível; (IEF5) Investimento e Inversão Financeira /Receita Disponível. Chegou a conclusão de que houve certa estabilidade nas finanças estaduais mineiras, com queda do (IEF1) revelando que a LRF foi a disciplinadora do ajuste fiscal independente do governo de plantão ${ }^{3}$. Fez ressalva em relação (IEF3) e (IEF4) que tratam de variáveis da despesa que foram onerosas após o Programa de Reestruturação e Ajuste Fiscal de 1998. Em relação ao volume de investimento medido pelo (IEF5) os valores foram baixos, apresentando-se como justificativa o déficit em infraestrutura; havendo destaque nos anos em que houve eleição no período. A avaliação é de que as limitações impostas pela LRF produziram tal resultado.

Em relação ao Programa de Reestruturação e Ajuste Fiscal de 1998 (PAF) foi sugerido: a) Redução do percentual da RCL para o pagamento da dívida. Foi acordado na assinatura da renegociação, os seguintes percentuais destinados ao pagamento dos encargos da dívida: $6.79 \%$ até 11/1998; $12 \%$ em 12/1998; 12,5\% em 1999; e 13\% após 2000; b) Revisão do índice de correção da dívida estadual: O índice aplicado como corretor é o IGP-DI (sensível a mudanças no câmbio e na taxa de juros). A mudança para o IPCA/IBGE seria um ganho relativo, por ser este índice menos sensível à volatilidade cambial; c) Revisão das taxas de juros da dívida: Na assinatura da renegociação estabeleceu-se a amortização de $20 \%$ da dívida, com juros de $6 \%$ a.a. ao estoque restante. Como o Estado de Minas Gerais pagou somente $10 \%$, foi empregada ao estoque restante uma taxa de $7,5 \%$.

Os Estados da região Nordeste não enfrentaram a situação que o Estado de Minas Gerais enfrentou. Segundo Mendes (2009) A evolução média do indicador de garantia (G/RCL) demonstra uma tendência de queda. No período de (2001-2005) foi registrado 5,5\% em comparação com 2006-2008 que foi de 1,6\%. O Estado de Alagoas por violar, em média, o limite da DCL/RCL ficou impossibilitado de estipular garantias, apresentando 0,00\%. Ao contrário, os estados de Sergipe $(10,57 \%)$ e do Ceará $(12,96 \%)$ que se destacaram na região uma vez que quase a metade apresentou valores médios abaixo de 1\% (AL, MA, PB e PE). Mendes (2009) ainda averigua o Resultado Primário (RP/RCL), em média, representou 8,91\% da RCL, e variou entre 4,57\% (Pernambuco) e 14,75\% (Alagoas). Sergipe atingiu 7,30\%.

\footnotetext{
${ }^{3}$ Itamar Franco de 1998-2002 e Aécio Neves de 2003-2010. 
Ressalta o autor que o resultado primário deve ser o bastante a fim de quitar as obrigações com juro e amortizações das dívidas públicas, mas que não deve progredir descontroladamente, pois isso representa a diminuição de investimentos fundamentais à satisfação de demandas sociais.

O trabalho desenvolvido por Mendes (2009) na avaliação do crescimento econômico dos estados do Nordeste utilizou como metodologia a modelagem econométrica com dados em painel, em que o modelo ad hoc foi estimado com efeitos fixos e com correção de heterocedasticidade e de autocorrelação entre os resíduos, realizando análise descritiva dos dados. Foram analisadas cinco variáveis independentes, que eram as medidas de desempenho determinadas pela LRF: resultado primário (RP), dívida consolidada líquida (DCL), garantia (G) e operações de crédito (OC). A variável dependente era taxa de crescimento anual do total expresso pelo PIB per capita. A estimativa dos parâmetros foi realizada com significância de 5\%. Com a Regressão Mínimos Quadrados Generalizados (MQG) o autor chegou à conclusão de que os sinais negativos e significantes nos coeficientes estimados das variáveis Resultado Primário $(-0,243794)$ e Dívida Consolidada Líquida $(-0,097598)$ estavam concordantes com a precaução existente em se limitar o Resultado Primário e a Dívida Consolidada Líquida, posto haver uma relação negativa entre estes e a taxa de crescimento econômico anual. $\mathrm{O}$ valor do coeficiente de RP foi -0,243794, o que significa que a cada acréscimo unitário de RP há um impacto negativo na $\mathrm{E}(\mathrm{y})$, de - 0,243794 (mantendo as demais variáveis independentes constantes). Em relação a DCL, cujo valor foi - 0,097598, e encontrado uma elasticidaderenda estimada de $-2,89$, resulta que a cada variação de $1 \%$ na DCL conduz, em média, a uma redução de $-2,89 \%$ na taxa de crescimento per capita.

Embora Giuberti (2005) tenha concluído que para a maior parte dos Municípios a Lei de Responsabilidade Fiscal não influiu na conduta dos gestores públicos no tema do gasto com pessoal; ela também avaliou a repercussão da LRF sobre os municípios que despendiam um gasto elevado com a despesa de pessoal. Para este estudo foi estimado um modelo logit de efeito fixo, cuja variável dependente assumia valor igual a um caso o município tivesse cumprido o limite determinado pela LRF naquele ano e zero na situação contrária. As variáveis de controle usadas no modelo também possibilitaram checar se havia alguma correlação entre o grau de dependência das transferências intergovernamentais e o gasto com pessoal. Foram adotadas oito variáveis explicativas: parcela de receita de transferência da União (prt-união); parcela de receita de transferência do Estado (prt-estado); população (número de pessoas residentes nos municípios); LRF, partidos efetivos (captam a influência 
do sistema eleitoral no gasto público); fracionalização (preferências dos eleitores sobre os candidatos à prefeitura do Município); partido esquerda (assumiu valor um caso o prefeito seja filiado a um partido de esquerda), polarização (representa o grau de participação dos partidos de esquerda na Câmara Municipal, no sentido de que quanto maior o grau de polarização maior seria o acúmulo de dívidas entre governos sucessivos, o que dificultaria o cumprimento do limite da LRF. Isto porque numa eleição a decisão se dá pela regra majoritária e a política implementada pelo governo é a preferida do eleitor mediano; e como há incerteza quanto às preferências majoritárias futuras, usa-se o gasto hoje para influenciar a composição do gasto futuro a seu favor).

Como resultado verificou-se que as variáveis prt_união e prt_estado apresentaram sinal negativo e significante, o que mostra que uma elevação de receita proveniente de transferências intergovernamentais conduz a maior gasto e diminui a probabilidade do município cumprir o limite estabelecido pela Lei. O aspecto político também influencia no resultado do cumprimento da Lei. Houve sinal negativo e significante da variável fracionalização, indicando que quanto mais dispersas forem as preferências do eleitorado menor é a probabilidade de se cumprir o limite; pois a maior dispersão das preferências compele a elevação de um gasto atual como forma do eleitor mediano assegurar o gasto de sua preferência. Já o número de partidos efetivos expressou um resultado diverso do esperado. $\mathrm{O}$ sinal positivo e significante mostrou que quanto maior o número de partidos importantes na arena política maior é a possibilidade do limite ser observado. Aguardava-se o contrário, já que um maior número de atores pende para onerar a negociação por apoio. Entretanto, há a probabilidade deste efeito esperado não se espelhar neste item da despesa pública. Podendo a negociação envolver a ocupação dos cargos já existentes e/ ou maiores verbas para outros serviços, e não a criação de cargos públicos.

As outras variáveis políticas não foram reputadas estatisticamente significantes, sendo excluídas do modelo, porque somente atinge marginalmente a amplitude dos coeficientes. A população afetou a possibilidade de cumprimento do limite de forma positiva e significante, o que informa um provável ganho de escala no fornecimento de bens e serviços públicos. Enfim, LRF é positiva e significante, expressando que embora não afetando o conjunto total dos municípios, ela é essencial para aqueles que apresentam um alto gasto com pessoal.

\section{Metodologia.}


A análise pretendida vai considerar os indicadores previstos na LRF aplicada ao Estado de Sergipe de 2001 a 2013. A Lei Complementar n. ${ }^{\circ}$ 101/2000, elencou uma serie de variáveis que uma vez relacionadas irão demonstrar o comportamento do gasto público, através do qual, em cotejo com os limites pré-estabelecido se observará o cumprimento aos ditames da citada norma legal.

Os dados recolhidos para análise foram produzidos pelo Estado de Sergipe e constam dos Balanços Gerais e do Relatório de Gestão Fiscal, ambos do Estado de Sergipe. O primeiro é uma determinação da Lei 4.320, de 17 de março de 1964, que dispõe sobre normas de elaboração e controle dos orçamentos e balanços dos três entes federativos. Já o segundo é uma exigência da Lei de Responsabilidade Fiscal, segundo disposição do art. 54 da LRF, que deve ser acessível ao público, inclusive eletronicamente. Também devem ser observadas as Resoluções do Senado Federal de n. ${ }^{\circ}$ 40/2001 e 43/2001, que dispõem sobre o limite da dívida pública consolidada e da dívida pública mobiliária de Estados, Distrito Federal e Municípios; e sobre as operações de crédito interno e externo e concessão de garantia, respectivamente.

A exposição da metodologia utilizada nesse trabalho aborda os métodos de pesquisa existentes com destaque para o método descritivo; segundo as lições de Naresh Malhotra.

Para Malhotra (2001, p.105) “A concepção de pesquisa é uma estrutura ou planta para a realização do projeto de pesquisa". Então, ela minudencia os procedimentos essenciais para o alcance das informações indispensáveis para construção ou elucidação de problemas de pesquisa. Assim, com um planejamento adequado se garante uma elaboração eficaz e eficiente de um projeto de pesquisa.

Os dois tipos principais de pesquisa podem ser classificados como exploratória e conclusiva. Na pesquisa exploratória o pesquisador investiga um problema ou uma situação para fornecer critérios e facilitar seu entendimento. A aplicação desse tipo de pesquisa ocorre quando é essencial determinar problemas com maior exatidão, reconhecer cursos importantes de ação, elaborar hipóteses, separar variáveis e relações - chave para análise subsequente, colher previamente dados complementares para o desenvolvimento de uma abordagem, estipular preferências para pesquisas futuras (MALHOTRA, 2001).

A pesquisa conclusiva submete as hipóteses a testes e observa relações. Apresenta as seguintes características: as informações essenciais são bem explicadas; o processo da pesquisa é formal e estruturado; a amostra é extensa e representativa e o exame dos dados é quantitativo. As pesquisas conclusivas se subdividem em descritivas ou causais; e as pesquisas 
descritivas ainda podem ser classificadas como transversais ou longitudinais. Como diz o nome, na pesquisa conclusiva as constatações são conclusivas e os resultados servem de dados para auxiliar decisões.

A pesquisa descritiva é uma espécie de pesquisa conclusiva que tem a finalidade de descrever algo, comumente características ou funções de alguma coisa. Como ela se utiliza de hipóteses específicas, com informações essenciais bem explicadas; isso conduz a uma pesquisa sempre pré-planejada e estruturada. Nesse tipo de pesquisa deve haver uma boa pormenorização de quem, o que, quando, onde, por que e o modo da pesquisa. Dados secundários; surveys, painéis, dados de observações e outros dados são os métodos que predominam numa pesquisa descritiva. Já numa concepção formal de pesquisa se explicita os métodos para a separação das fontes de informações e a reunião de dados das mesmas.

A presente exposição é focada no método conclusivo descritivo, e como mencionado, acima onde os métodos se interpõem em função da necessidade da pesquisa, ora ela se apresenta com aspectos transversais, ora com feições longitudinais.

\section{Panorama do desenvolvimento no estado de Sergipe.}

\subsection{Finanças públicas e LRF no governo do Estado de Sergipe}

Sergipe como unidade da federação do Brasil não se comportou diferente das demais no tocante a captação de recursos por meio de operações de empréstimos e financiamentos externos, todos afiançados pela União. Entretanto, como já mencionado, a restrição dos financiamentos externos, devido a crise dos anos 80, levou à diminuição do crédito e a inadimplência. Esta situação conduziu ao processo de renegociação de dívida externa do setor público, autorizado pela Lei 7976/89. Posteriormente, em 1993, houve renegociação da dívida interna estadual, autorizada pela Lei 8727. Esta dívida foi originada de investimentos em infraestrutura. Finalmente como precursora da LRF, a Lei 9496/97, permitiu o derradeiro financiamento de dívidas; agora, porém, com imposição de condições, com maior rigor no controle das finanças públicas. No período do governo de João Alves Filho (15/03/1991 a 01/01/1995) foram emitidos títulos da dívida pública, que como não foram quitados no vencimento, gerou inadimplência, compelindo o Estado a fazer uma renegociação ao amparo da Lei 9497/97. Também foi incluída dívida do platô de Neópolis.

\section{Tabela 1- Dívida Pública Fundada da Administração Direta}




\begin{tabular}{lrrr}
\hline \multicolumn{1}{c}{ Ano (moeda) } & $1989(\mathrm{Ncz} \$)^{4}$ & \multicolumn{1}{c}{$1993(\mathrm{CR} \$)^{5}$} & \multicolumn{1}{c}{$1997(\mathrm{R} \$)$} \\
\hline Dívida Externa & $191.593 .806,95$ & $5.513 .755 .281,69$ & $712.412 .737,14$ \\
Dívida Interna & $929.884 .348,71$ & $39.168 .476 .438,21$ & $34.017 .453,17$ \\
Total & $1.121 .478 .155,66$ & $44.682 .231 .719,90$ & $746.430 .190,31$ \\
Atualizado IPCA dez/2013 (R $\$)$ & $729.909 .884,36$ & $848.299 .706,69$ & $1.993 .931 .279,14$ \\
\hline Fonte: (SERGIPE $1989,1993,1997 \mathrm{a})$ & & &
\end{tabular}

A finalidade da Tabela 1 acima é mostrar como estava a situação das dívidas, no momento em que foram assinados os contratos de financiamento ou refinanciamento. Mostram-se os saldos de dívida interna e externa do Estado de Sergipe apurada em dezembro do ano em destaque, ou seja, ano anterior à assinatura dos respectivos contratos e que serviram de base para os pedidos de refinanciamento das dívidas junto ao governo federal.

\section{Quadro 1- Contratos de Refinanciamento de Dívidas}

\begin{tabular}{|c|c|c|c|c|c|c|}
\hline Número & $\begin{array}{c}\text { Data da } \\
\text { assinatura }\end{array}$ & $\begin{array}{c}\text { Tipo de } \\
\text { dívida }\end{array}$ & moeda & $\begin{array}{c}\text { Valor Contratual } \\
\text { (nominal) }\end{array}$ & $\begin{array}{c}\text { Valor } \\
\text { atualizado (R\$) }\end{array}$ & $\begin{array}{c}\text { Governador do } \\
\text { Estado celebrante } \\
\text { do Contrato }\end{array}$ \\
\hline $282 / 90$ & $29 / 06 / 1990$ & Externa & $\mathrm{Cr} \$$ & $104.542 .122,25$ & $6.728 .785,02$ & $\begin{array}{c}\text { Antonio Carlos } \\
\text { Valadares }^{7}\end{array}$ \\
\hline $25.840 / 94$ & $23 / 03 / 1994$ & Interna & $\mathrm{CR} \$$ & $115.590 .187 .740,29$ & $809.067 .340,27$ & João Alves Filho $^{8}$ \\
\hline $005 / 97$ & $27 / 11 / 1997$ & $\begin{array}{c}\text { interna e } \\
\text { externa }\end{array}$ & $\mathrm{R} \$$ & $355.163 .152,56^{9}$ & $950.356 .538,16$ & Albano Franco $^{10}$ \\
\hline
\end{tabular}

Fonte: (SERGIPE 1990, 1994, 1997b).

Valor Atualizado pelo IPCA dez/2013

O Quadro 1 apresenta respectivamente o número do contrato celebrado pelo governo do Estado, a data de sua celebração, o tipo de dívida a que se referia, a moeda em vigor, o valor contratual nominal, o valor atualizado e o governador celebrante do mesmo. Lembrando que os valores contratados expressados acima foram atualizados até a data da assinatura dos documentos. Em todos os três contratos havia cláusula prevenindo a inadimplência, através da retenção da parte do Fundo de Participação dos Estados (FPE) e dos impostos estaduais que bastassem para a quitação da parcela.

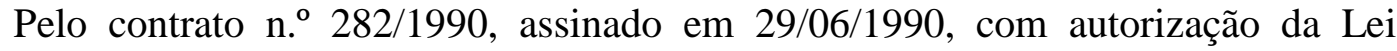
7976/1989, e da Lei Estadual n. ${ }^{\circ}$ 2805/1990, o Estado de Sergipe promoveu o refinanciamento

\footnotetext{
${ }^{4} \mathrm{Ncz} \$=$ cruzados novos. Vigorou de 16/01/1989 a 15/03/1990.

${ }^{5} \mathrm{CR} \$=$ cruzeiro real. Vigorou de 1/08/1993 a 30/06/1994.

${ }^{6} \mathrm{Cr} \$=$ cruzeiro. Vigorou de 16/03/1990 a 31/07/1993.

7 Período de governo: 15/03/1987 a 15/03/1991

${ }^{8}$ Período de governo: 15/03/1991 a 01/01/1995

9 O valor refinanciado foi reduzido por conta da parcela amortizada pela venda da Energipe.

${ }^{10}$ Período de governo: 01/01/1995 a 01/01/1999 (eleito); 01/01/1999 a 01/01/2003 (reeleito)
} 
de sua dívida externa do empréstimo ponte concedido pelo governo federal com base no Aviso MF 030/83, pelo prazo de 20 anos. Os encargos financeiros envolviam os juros LIBOR acrescida de "spread" de 0,8125\% a.a. Assim, a dívida externa no valor de U\$ 8.019.270,99, ou $\mathrm{Cr} \$ 90.633 .800,72$; foi financiada por $\mathrm{Cr} \$ 104.542 .122,24$, que atualizada pelo IPCA de dezembro/2013, corresponde a $\mathrm{R} \$ 6.728 .785,02$.

Através do contrato n. ${ }^{\circ}$ 25.840/1994, com a permissão tanto da Lei 8727/1993, que trata do Programa de Saneamento do Setor Público, como da Resolução do Senado Federal n. ${ }^{\circ} 11 / 94$ e da Lei Estadual n. ${ }^{\circ} 3427 / 1993$, o governo do Estado celebrou o contrato de refinanciamento de dívida interna, em 23/03/1994. A dívida era composta de Empréstimos da CEF no valor de CR\$ 112.664.286.401,66, que foi atualizada através da taxa de referência TR e de CR \$ 2.836.999.336,13 da dívida junto ao Banco Nacional de Desenvolvimento Econômico - BNDES, também atualizada através da taxa de referência - TR, e por fim pelo débito de CR \$ 88.902.002,50 junto ao governo federal e atualizada índice geral de preços do mercado- IGPM. Assim, o montante total importou em CR \$ 115.590.187.740,29. Atualizado tudo por um único índice, o IPCA de dezembro/2013 alcançaria o valor de $\mathrm{R} \$$ 809.067.340,27.

Já em 27 de novembro de 1997, o Estado de Sergipe e a União estabeleceram Contrato de Confissão, Promessa de Assunção, Consolidação e Refinanciamento de Dívidas (Contrato ${ }^{\circ}$ 005/97/STN/COAFI), ao amparo da Lei 9.496/1997, na esfera do Programa de Apoio à Reestruturação e ao Ajuste Fiscal dos Estados, e na Resolução nº 108/96, do Senado Federal, assim como na Lei Estadual n. ${ }^{\circ}$ 3.785/96. Com a assinatura deste contrato, o governo do Estado começa a implementar uma serie de ações exigidas para sua celebração, tais como privatização da Energipe, saneamento do Banese, Programa de Desligamento Voluntário PDV, a fim de equilibrar as contas públicas devido a estabilidade da moeda e a perda do imposto inflacionário, já que a arrecadação das receitas devido a queda da inflação e o aumento das receitas não era o bastante para ultrapassar os gastos públicos.

Por este Contrato e os instrumentos próprios, a União assumiu a totalidade da dívida mobiliária e os contratos do Estado junto à Caixa Econômica Federal, no valor total de $\mathrm{R} \$ 355.163 .152,56$. Destes, $\mathrm{R} \$ 41.226 .877,37$ correspondeu a parcela amortizada com bens e direitos, registrada em conta gráfica (amortização extraordinária de 20\% (vinte por cento) do valor do financiamento da dívida mobiliária estadual por ocasião do leilão de privatização da Empresa Energética de Sergipe S.A. - ENERGIPE). Restou ao Estado como parcela refinanciável o valor total de $\mathrm{R} \$ 313.936 .275,19$. 
Esta dívida é composta de $\mathrm{R} \$ 206.134 .386,83$, referente à dívida mobiliária; $\mathrm{R} \$$ 122.287.594,30 de Empréstimos da CEF (Votos CMN n. ${ }^{\circ} 162 / 95,175 / 95$ e 122/96) e de R\$ 26.741.171,43 da dívida com o BNDES.

O jornalista Santos (1997) informou que grupo mineiro Cataguazes-Leopoldina, em 03 de dezembro de 1997, comprou 86,42\% do capital da Empresa Energética de Sergipe (Energipe) por R $\$ 577,1$ milhões, com ágio de 96,06\% sobre o preço mínimo. Este foi o maior ágio alcançado em um leilão de privatização do setor elétrico brasileiro. Segundo o próprio governador da época, em entrevista a Nascimento (2011, p. 2) Albano Franco comentou que:

o programa de reestruturação do setor público estadual teve como objetivo central resgatar a capacidade de investimento do governo do Estado que naquela época estava abaixo de zero, ou seja, era negativa, já que a receita líquida era toda comprometida com as despesas de pessoal e pagamento da dívida.

E que com a privatização da Energipe continua Albano Franco

\begin{abstract}
viabilizamos financeiramente o Estado e afastamos a possibilidade concreta de uma intervenção federal, a exemplo do que ocorreu com o vizinho Estado de Alagoas (...) possibilitou o equilíbrio das contas públicas e a recuperação da capacidade de investir do Estado, tanto em obras públicas indispensáveis como em parceria com a iniciativa privada (NASCIMENTO, 2011, p. 2).
\end{abstract}

O Banco do Estado de Sergipe, que no passado atuava como os demais bancos estaduais financiando diretamente o tesouro estadual, sem obediência as determinações da autoridade monetária, após a estabilização da moeda com o plano real, em 1994, atravessou dificuldade financeiras, mas não foi fechado e nem privatizado. De acordo com o Proes, o governo resolveu deixá-lo sob controle do Estado, aplicando, em 1997, R\$ 40.984.621,43 oriundos da venda da Energipe na sua recuperação (SERGIPE, 1999).

Ainda precisa ser mencionado que o Poder Executivo foi autorizado a contratar operação de crédito, em nome do Estado de Sergipe junto à Caixa Econômica Federal (CEF), ou outras instituições financeiras nacionais, até o montante de $\mathrm{R} \$ 50.000 .000,00$ (cinquenta milhões de reais), para atender despesas decorrentes da execução do Programa de Desligamento Voluntário da Administração Pública do Estado de Sergipe (PDV/SE) (Lei 3811, de 14/04/1997, art. 17). O governo sergipano desembolsou exatamente R $\$ 50$ milhões, segundo o balanço geral de 1997.

O refinanciamento consentido pela Lei 9496/97 é reputado o mais relevante, pelo fato do governo federal ter imposto condições rigorosas para serem cumpridas, o que não aconteceu com os refinanciamentos anteriores, contribuindo assim para um direcionamento 
das finanças públicas além de preparar o terreno para as imposições da LRF. Por isso, o Estado de Sergipe, diante do contrato assumido, precisa cumprir as metas ou compromissos do Programa de Reestruturação e de Ajuste Fiscal estabelecidos em relação: Meta1: Dívida financeira em relação à receita líquida real (RLR); Meta 2: Resultado primário, Meta 3: Despesa com pessoal; Meta 4: Arrecadação de receitas próprias, Meta 5: Reforma do Estado, ajuste patrimonial e alienação de ativos; Meta 6: Despesas de investimento.

Meta1: Dívida financeira em relação à receita líquida real (RLR). A dívida financeira deve ser menor ou igual à receita líquida real. Ou seja, a relação entre a dívida financeira e a RLR deve ser menor ou igual a 1.

A definição de Receita Líquida Real (RLR) é encontrada no parágrafo único do art. $2^{\circ}$ da Lei 9496/97, correspondendo ao montante da receita realizada. Ou seja, o somatório das receitas orçamentárias de todas as fontes exceto o sistema previdenciário; deduzidos: as receitas de operações de crédito; as receitas de alienação de bens, as receitas de transferências voluntárias ou de doações recebidas com o fim específico de atender despesas de capital, as receitas de transferência de que trata o art. 83 da Lei 12.249, de 11/06/2010; os recursos de que trata $o$ art. $5^{\circ}$ da Lei 10.195/01, com redação dada pela Lei 11.533/07, os recursos provenientes de repasses do Fundo Nacional de Saúde a título de Gestão Plena do Sistema Estadual de Saúde, conforme previsto no Parecer PGFN/CAF n. ${ }^{\circ} 1.331$, de 31/08/2004 e as despesas com transferências constitucionais e legais aos municípios.

Nessa meta 1, quando o PAF trata de dívida financeira ele considera o estoque das dívidas financeiras de contratos de financiamento, de refinanciamento e de parcelamento de outras dívidas com a União (FGTS, INSS) suportadas pelo Tesouro do Estado. Quando se observa a LRF, esta menciona o passivo exigível total. Ou seja, o limite da LRF para a dívida consolidada líquida é de 2 X RCL, quer dizer, 2 X o estoque da dívida (art. $3^{\circ}$, I da Resolução Senado Federal n. ${ }^{\circ}$ 40/2001). Isso significa que o limite a ser imposto pela LRF ficou mais brando que o limite imposto pelo PAF. A multiplicação por dois levou a um limite de dívida muito alto, que só as unidades federadas mais desenvolvidas atingiriam. Então, percebe-se que o PAF é mais rigoroso.

A RLR leva em conta apenas as receitas arrecadadas pela fonte "Tesouro", já a RCL engloba todas as receitas orçamentárias arrecadadas (quer dizer, administração direta, autarquias, fundações e estatais dependentes). Por isso, a RCL é maior que a RLR.

Meta 2: Resultado primário. Esta meta visa que se busque atingir o resultado primário estipulado; sendo que este é obtido através da diferença entre receita primária e 
despesa primária (não financeiras). Sua definição e forma de apuração seguem o Manual de Demonstrativos Fiscais elaborados pela Secretaria do Tesouro Nacional (STN).

As receitas primárias equivalem o total das receitas orçamentárias deduzidas as operações de crédito, as oriundas de rendimento de aplicações financeiras e as devoluções de juros e amortizações das operações de crédito, além da obtenção de recursos provenientes de empréstimos concedidos e as receitas de privatizações. As Despesas primárias representam o total das despesas orçamentárias subtraídas às despesas com juros e amortização da dívida interna e externa, com a obtenção de títulos de capital integralizado e as despesas com concessão de empréstimos com retorno garantido (ANDRADE, 2012).

Havendo resultado primário positivo chama-se superávit primário, e quando é negativo, ocorre um déficit primário. A busca pelo superávit primário é um modo de redução de endividamento porque traz subjacente o entendimento de que se reduziu despesa e/ou aumentou receita, conduzindo a uma menor necessidade de recursos para o financiamento do ente federado. Assim, o resultado primário precisa ser o bastante para satisfazer o pagamento de serviços da dívida, possibilitando uma redução do estoque total da dívida líquida. Se por outro lado, há um déficit primário, então se demonstra que há um avanço da dívida; se está pagando dívida com dívida ou se está inadimplente.

A interpretação do resultado primário é a mesma tanto para o PAF como para LRF. No entanto, no caso da LRF quando o desempenho da receita ao final de um bimestre não é compatível com a efetivação das metas de resultado primário ou nominal deve haver limitação de empenho e movimentação financeira por parte dos Poderes e do Ministério Público; conforme disposto na LDO (art 4", I, "b" e art. 9 LRF), ou mesmo um reexame da programação de desembolso (art. $8 \mathrm{LRF}$ ). Em obediência ao art. 165, §3º da Magna Carta, o Relatório Resumido da Execução Orçamentária - RREO deve ser acompanhado de demonstrativo referente ao resultado primário (art. 53, III da LRF). Na LRF, basta que haja o resultado primário, e sua explicação quando for negativo, não havendo uma meta a ser buscada; e nem consequências negativas.

No caso do PAF, o resultado primário tem uma meta a ser perseguida pelo ente federado. Quando não atingido deve haver uma justificativa robusta por parte do Estado, o chamado pedido de perdão - waver, a ser protocolada junto ao Ministério da Fazenda, sob pena de ser aplicada as seguintes sanções (i) a substituição dos encargos financeiros por encargos equivalentes ao custo médio de captação da dívida mobiliária interna do Governo Federal, acrescido de juros de $1 \%$ a.a, (ii) a elevação, em quatro pontos percentuais, do 
percentual da RLR tomado como base para apuração do limite de dispêndio mensal previsto no próprio contrato; além da proibição de contratação de operações de crédito.

Meta 3: Despesa com pessoal. O PAF objetiva delimitar a despesa com pessoal a $60 \%$ da receita corrente líquida (RCL). Nesse caso, o limite de 60\% é global, não havendo divisão entre os Poderes. A metodologia de cálculo desta RCL é diferente da adotada pela LRF, que se utiliza da mesma nomenclatura receita corrente líquida (RCL). Se o valor dessa meta for ultrapassado nos próximos três anos, o Estado deverá promover ações direcionadas a conter o aumento da folha de pagamento; para tanto deve fazer o controle e a gestão de benefícios, de incorporações de benefícios pessoais, como também implementar medidas de produtividade e auditoria constante nos gastos com funcionalismo público.

A LRF trouxe a mesma limitação de gastos com pessoal em $60 \%$. No entanto, distribuiu este limite entre os Poderes. Os art. 22 e 23 da LRF prevêem vedações para o caso de desrespeito ao limite prudencial estabelecido. A proibição vai desde o impedimento a criação de cargo, emprego ou função; alteração de estrutura de carreira, provimento de cargo público ou contratação de pessoal até a punição materializada na restrição das transferências voluntárias e na proibição de contratar operações de crédito e obtenção de garantia. Este indicador da LRF fica bastante prejudicado porque o Poder Executivo não tem competência para fazer com que os demais Poderes obedeçam coercitivamente a tal determinação. Assim, o descumprimento desta meta penaliza o Poder Executivo, pelo fato dos empréstimos serem tomados pelo Estado na pessoa do Poder Executivo. A punição é materializada na restrição das transferências voluntárias e na proibição de contratar operações de crédito.

Meta 4: Arrecadação de receitas próprias. Objetiva atingir o montante da receita projetada. Para tanto, o Estado deve aperfeiçoar os mecanismos de administração fiscal especialmente com foco na arrecadação do ICMS e IPVA, que representam o carro chefe da arrecadação; fazer um apanhado dos débitos fiscais em aberto, com a respectiva etapa ou condição do processo fiscal, além de racionalizar e modernizar os sistemas de controle da fiscalização e arrecadação, identificando os pontos de estrangulamento de arrecadação de certas atividades econômicas.

Meta 5: Reforma do Estado, ajuste patrimonial e alienação de ativos. Esta meta não é quantificada. Ela representa um conjunto de ações a serem desenvolvidas. O relatório da $14^{\text {a }}$ revisão, período 2013-2015 do Programa de Reestruturação e Ajuste Fiscal do Estado de Sergipe, de 18/12/2013, aponta as pretensões do governo estadual que já estão com trabalhos iniciados desde 2009, e que avançam aos poucos: 
Conservar na esfera do Poder Executivo Estadual, Grupo de Procedimentos Contábeis do Estado de Sergipe (GTCON/SE), com a intenção de efetuar um planejamento estratégico para a adoção de medidas com vias de: adequar a contabilidade pública estadual aos quesitos do Manual de Contabilidade Aplicada ao Setor Público- MCASP; empregar o novo Plano de Contas Aplicado ao Setor Público- PCASP. Também se pretende adotar um sistema de custos que: possibilite analisar e evidenciar os resultados da gestão; calcule os custos dos programas e das unidades da administração pública estadual e, permita confrontar informações com outros entes federados.

O governo também pretende garantir uma estrutura técnico-institucional de acompanhamento de empresas estatais dependentes. Quer ainda assegurar uma estrutura técnico-institucional de monitoramento do Programa, com atuação de integrantes das Secretarias da Fazenda, do Planejamento e Administração e da Controladoria Geral do Estado.

Manter atualizado o Sistema de Coleta de Dados Contábeis (SISTN), na Caixa Econômica Federal, de acordo com os normativos vigentes, é outro objetivo da meta 5. Acrescenta-se o compromisso de enviar à STN Relatório sobre a execução do Programa de Reestruturação e Ajuste Fiscal do Estado, relativo ao exercício anterior e sobre as perspectivas para o triênio seguinte (Relatório do Programa), até o dia 31 de maio de cada ano, onde constará exame minucioso do cumprimento ou descumprimento de cada uma das metas ou compromissos, assim como sobre as ações realizadas e, finalmente anunciar os dados e informações relativos ao Programa de Reestruturação e Ajuste Fiscal do Estado, segundo as prescrições do $\S 1^{\circ}$ do art. $1^{\circ}$ da Lei Complementar n. ${ }^{\circ} 101$, de 4 de maio de 2000, até mesmo com o uso de meios eletrônicos de acesso público.

Por fim, também se pretende preservar um sistema de Gestão do Patrimônio Móvel e Imóvel do Estado, o qual compreende uma solução logística e informatizada de gestão pública em plataforma web, com fornecimento de software.

Meta 6: Despesas de investimento. Baseia-se na delimitação das despesas de investimento e de inversões, conforme os percentuais de RLR previsto.

Havendo o cumprimento integral das metas 1 e 2, quais sejam dívida financeira em relação à RLR e o resultado primário, o Estado será considerado adimplente para todos os demais efeitos. Assim sendo, havendo o descumprimento das demais metas, o Estado pode tentar medidas para restabelecê-las sem nenhuma sanção. (art. 26, III da Medida Provisória n. ${ }^{\circ}$ 2.192-70, de 24 de agosto de 2001, com redação alterada pela Lei 10.661, de 22 de abril de 2003). 
Devido a celebração do Contrato $\mathrm{n}^{\circ}$ 005/97/STN/COAFI, e a característica da alternância de revisão de metas, compromissos e ações do Programa de Apoio à Reestruturação e ao Ajuste Fiscal dos Estados, o grupo de técnicos da STN juntamente com os técnicos da Sefaz/SE, reúnem se anualmente para definições do exercício em curso e de dois exercícios futuros.

No Anexo $\mathrm{C}$ se vislumbra as metas e os valores realizados desde o início da vigência da Lei de Responsabilidade Fiscal até 2013; onde o Estado vem cumprindo com o acordado. Entretanto, nos exercícios, 2003, 2004 e 2006, nessa ordem, Sergipe produziu um resultado primário em milhões de $\mathrm{R} \$ 83,2 ; \mathrm{R} \$ 30,7$ e $\mathrm{R} \$-1,4$, em descumprimento ao resultado primário estipulado de que fosse maior ou igual, respectivamente, em milhões a $\mathrm{R} \$$ 125,0; $\mathrm{R}$ \$ 60,0; $\mathrm{R}$ \$ 89,0; o que implicou na impossibilidade de contratação de operações de crédito nos exercícios seguintes correspondentes. Assim, o período de 2003 a 2006, que correspondeu ao governo de João Alves Filho, os valores liberados referentes a esta rubrica foram oriundos de contratos anteriores a esse lapso temporal. Por isso mesmo, a ponte Construtor João Alves, vulgo ponte Aracaju- Barra dos Coqueiros inaugurada em setembro/2006 foi construída com recursos próprios. Ainda com respaldo neste descumprimento o ano de 2007 não foi contemplado com operações de crédito, e no ano de 2008, já sob nova gestão também não houve contratação. Vide o exposto nos Anexos J e L.

Já o descumprimento observado quanto a inobservância da meta de receita própria em 2009 e do excesso de gasto com pessoal em 2011, conforme já explicado não acarretou punição ao Estado, devido o foco do PAF ser a obediência às metas 1 e 2.

Para que se entenda o que os indicadores da LRF no Estado de Sergipe expressam faz-se necessário compreender o que se encontra no entorno do cumprimento da LRF. Ou seja, o desempenho das receitas estaduais, a evolução da Dívida Consolidada e Dívida Consolidada Líquida, a Dívida Contratual Interna e Externa, o comparativo das operações de crédito em relação aos investimentos, inversões financeiras, despesas correntes e pessoal e encargos sociais, bem como o desempenho do PIB. E é o que será visto nas próximas seções, com a elaboração de tabelas constante do anexo para facilitar a percepção.

\subsubsection{Principais receitas estaduais}

De acordo com a Lei 4320/64, em seu art. 11, estão elencadas as receitas estaduais segundo a categoria econômica. Elas se subdividem em receitas correntes e receitas de capital. 
As receitas correntes representam as fontes próprias de recurso e que devem provir de receitas tributárias (impostos (ICMS, IPVA, ITCD, IRRF- imposto de renda retido na fonte), taxas, contribuições de melhoria); receitas patrimoniais (imobiliárias, de valores mobiliários, participações e dividendos, outras receitas patrimoniais); receitas industriais (serviços industriais, outras receitas industriais), transferências correntes (destacam-se o Fundo de Participação do Estado (FPE); royalties do petróleo e gás natural, Contribuição de intervenção no domínio econômico (CIDE), Fundo de Manutenção e Desenvolvimento da Educação Básica (FUNDEB), Fundo Nacional de Desenvolvimento da Educação (FNDE), receitas diversas provenientes de multas, cobrança da Dívida Ativa e outras receitas diversas. Seus valores são obtidos do Balanço Geral do Estado de Sergipe.

As Receitas de Capital são voltadas ao atendimento de despesas com investimento, sendo formada por operações de crédito, alienação de bens, amortizações de empréstimos, transferências de capital e demais receitas de capital. Tem previsão legal no art. $11, \S 2^{\circ}$ da Lei 4.320/64. Seu valor pode ser obtido no Balanço Geral do Estado de Sergipe.

As receitas tributárias da competência estadual conforme reza a Constituição Federal de 1988 no art. 155 são o imposto de transmissão causa mortis e doação de quaisquer bens ou direitos (ITCD); o imposto sobre operações relativas à circulação de mercadorias e sobre prestações de serviços de transporte interestadual e intermunicipal e de comunicação ICMS e o imposto sobre a propriedade de veículos automotores (IPVA). Alem disso, o Estado também pode instituir taxas (pelo exercício do poder de polícia e pela prestação de serviços públicos) e contribuição de melhoria.

O ICMS conhecido como o imposto sobre o valor agregado brasileiro (IVA) é o principal imposto do sistema tributário nacional, por ser o maior tributo individualmente arrecadado, não só pela receita coletada que em $2013^{11}$ foi de $20,0 \%$ do total nacional; importando num montante de $\mathrm{R} \$ 360,9$ bilhões, mas também pela natureza e volume das operações envolvidas, já que incide não só sobre mercadorias, mas ainda sobre transportes intermunicipais, interestaduais e de comunicação. No ano 2013, a arrecadação de todos os impostos estaduais representou somente $26 \%$ da arrecadação nacional. Veja se, assim, a relevância do ICMS que sozinho representa $20 \%$.

\footnotetext{
${ }^{11}$ A União arrecadou em 2013, 67,8\% (R \$ 1.219,1 bilhões) do total de tributos do país de R \$ 1.798,9 bilhões. Só em impostos federais foram arrecadados R $\$ 369,2$ bilhões, ou seja, 20,5\% do total; e em contribuições sociais arrecadou $19,7 \%$. Os municípios responderam por apena $6,2 \%$ do total de tributos ao arrecadarem $\mathrm{R} \$ 111,8$ bilhões. Fonte: quadro elaborado por Afonso (2014b) para o Balanço do ano 2013, a partir do Balanço Oficial da União, Secretaria do Tesouro Nacional, Finanças do Brasil, Balanço dos Estados, Secretaria da Receita Federal.
} 
As receitas estaduais que tem um maior peso na arrecadação se constituem das receitas correntes formadas pelo ICMS e o FPE. Como a LRF trouxe um novo conceito, o de RCL e com ele parametrizou os diversos indicadores e cálculos existentes na lei, as receitas foram agrupadas e deduzidas de modo a se obter a RCL. Para tanto, foi elaborada a Tabela do Anexo D- Comparativo ICMS, FPE, OR, Deduções e RCL (valor atualizado IPCA dez/2013), que busca apresentar os valores das principais receitas do Estado ao longo do período 2001 a 2013. Onde OR- outras receitas englobam outras receitas tributárias, contribuições, receitas patrimoniais, receita de serviços, receitas agropecuárias, receitas industrial, outras transferências correntes, outras receitas correntes e Receita Corrente Líquida das empresas estatais dependentes. As Deduções englobam transferências constitucionais aos municípios, contribuições do servidor ao seguro social IPES FUNASERP, compensação financeira (art 21, $\left.\S 9^{\circ} \mathrm{CF} / 88\right)$, dedução para o FUNDEF.

O Anexo D mostra que o ICMS, a principal receita tributária estadual, cresceu 104,39\%; o que demonstra o esforço arrecadatório desenvolvido pelo Estado para arrecadar suas receitas próprias. Entre 2001/2002, o ICMS teve um decréscimo de 5,68\%; porém veio apresentando crescimentos sucessivos com a maior alta do período em estudo entre 2005/2006, quando cresceu $19,70 \%$ e posteriormente em 2009/2010, com incremento de $17,12 \%$. À época da crise de 2008, o ICMS apresentou um crescimento de apenas $2,48 \%$ no intervalo 2008/2009, em contraposição ao crescimento de 4,30\% no período 2007/2008.

No entanto, o Fundo de Participação dos Estados- FPE, que faz parte das transferências correntes, sempre foi a maior fonte individual de recursos do Estado de Sergipe, incrementou apenas $86,47 \%$. O FPE é um fundo constitucional composto de $21,5 \%$ da receita líquida do imposto de produtos industrializados - IPI e do imposto de renda- IR. Estes dois impostos são de competência da União; e no caso do IPI que tem a extrafiscalidade como característica principal; implica dizer que além de servir para a arrecadação tributária federal, serve de instrumento para o controle e intervenção de setores da economia nacional, incentivando ou desestimulando ações. Tanto é assim que autorizado pela Constituição Federal de 1988, o Chefe do Executivo Federal pode modificar suas regras por decreto e sem obediência ao princípio da anterioridade tributária ${ }^{12}$. Neste aspecto este imposto tem servido para superação de crises, com o estímulo a produção nacional e ao consumo. Como se sabe

\footnotetext{
${ }^{12}$ Princípio de direito tributário que estabelece não poder haver cobrança de tributo no mesmo exercício em que tenha sido criado ou majorado.
} 
não só por conta da crise financeira internacional de 2008, extremamente danosa à economia nacional, mas há algum tempo, o governo federal tem desonerado muitos segmentos o que impacta diretamente no valor arrecadado e partilhado com os demais entes federados à conta do IPI.

Entre 2005 e 2008, o FPE teve seu maior crescimento, coincidente com o momento de crescimento econômico do país. Atingiu o maior valor em 2005/2006, quando se elevou em 26,39\%. A partir de 2009, seu crescimento tem oscilado apresentando crescimento negativo no lapso 2008/2009, de 7,52\%, chegou a aumentar $15,51 \%$ no período $2010 / 2011$, mas em 2012 e 2013 declinou novamente apresentando, nesta ordem, crescimento negativo de $2,3 \%$ e positivo de apenas $0,75 \%$.

Percebe-se também no Anexo D que as outras receitas se elevaram em 161,08\%. Assim, o total das Outras Receitas Correntes teve um acréscimo de 110,75\%. Já as deduções apresentaram o maior crescimento do período, chegando a 231,15\%. Como já mencionado, a queda no FPE tem um impacto imediato sobre a Receita Corrente Líquida, que se ampliou apenas em 86,79\%, em sintonia com a diminuição do FPE. Como a base da RCL são as receitas correntes se vislumbrou um desempenho muito próximo ao do FPE.

No Anexo E também se encontram os valores nominais.

6.2.2 Evolução da Dívida Consolidada (DC) e Dívida Consolidada Líquida (DCL) 2001-2013

A prestação dos serviços públicos passa pelo fornecimento de bens e serviços. Assim, o gasto público é algo inerente ao cumprimento das atividades essenciais do governo. Mas o gasto precisa ser de qualidade. A dívida pública consolidada ou fundada leva em conta o montante total, apurado sem duplicidade, de todas as obrigações financeiras do Estado de Sergipe contraídas por força de leis, contratos, convênios ou tratados como também a consumação de operações de crédito, para amortização em prazo superior a doze meses (art. 29,I LRF e art. $2^{\circ}$, III Resolução do Senado Federal n. ${ }^{\circ}$ 43/2001). Quando se retiram as disponibilidades de caixa, as aplicações financeiras e os demais haveres financeiros se obtêm a dívida consolidada líquida- DCL.

O Anexo F mostra que no período a Dívida Consolidada- DC se elevou em 39,48\%, saindo de $\mathrm{R} \$ 2.570 .663 .744$ para $\mathrm{R} \$ 3.585 .586 .725$. A dívida consolidada líquidaDCL apresentou um crescimento menor, em torno de 29,37\%, ao sair de $\mathrm{R} \$ 2.302 .489 .423 \mathrm{em}$ 2001 para R \$ 2.978.711.956 em 2013. Se fizermos a comparação com a RCL será visto um incremento de $86,79 \%$. 
Agora, fazendo uma comparação entre a variação anual da dívida consolidada líquida e a receita corrente líquida percebe-se que entre 2001 e 2005, a evolução da DCL foi negativa, em contraste ao crescimento positivo da RCL, exceto em 2002. No entanto, a DCL dá um salto de 38,14\% entre 2005/2006, para um aumento de apenas 9,66\% na RCL no mesmo intervalo. A DCL volta a ser negativa em 2007 e 2008, para um crescimento positivo da RCL.

A partir de 2009, a dívida tem se elevado significativamente, em relação ao crescimento da RCL. Cresceu 21,27\% entre 2008/2009; enquanto a receita decresceu 0,65\%. Entre 2009/2010 a DCL cresceu 39,14\% e a RCL apenas 11,39\%. Entre 2010/2011 a DCL cresceu 37,96\% enquanto a RCL decresceu 0,63\%. Entre 2011/2012 a DCL aumentou 18,22\% e a RCL somente $0,86 \%$. Entre 2012/2013 tanto a DCL como a RCL apresentaram um crescimento negativo. Ou seja, a DCL recuou em $1,37 \%$ e a RCL em $0,89 \%$.

Sucintamente, pode-se verificar a existência de 02 períodos: a) um que ocupa o lapso temporal 2001 a 2008, exceto, o ano de 2006, e nesse período houve uma diminuição na dívida em 52,38\%, em relação ao crescimento de 69,93\% da RCL; b) o segundo período se inicia em 2009 indo até 2013. Nesse período, a DCL se elevou em 129,82\% ao sair de R\$ 1.330.828.574 em 2009 para R\$ 2.978.711.956 em 2013. Já a RCL teve um modesto incremento de $10,64 \%$ ao sair de $\mathrm{R} \$ 4.992 .835 .655$ em 2009 para $\mathrm{R} \$$ 5.524.274.805.

A relação DC/RCL ou DCL/RCL apresentará números que estimulam o aumento da dívida como será visto na Tabela 2 que trata dos indicadores de Sergipe para a LRF. Embora o limite superior da Dívida Consolidada Líquida (DCL) seja 2 vezes a RCL, existem outros limitadores de dívida constantes da própria lei. São eles: o serviço da dívida, que não pode ultrapassar 11,5\% da RCL ao ano, entre amortização, juros e encargos e as operações de crédito interna e externa que não podem ter liberações anuais que excedam a $16 \%$ da RCL. Isso quer dizer que há um limite à entrada de recursos (operações de crédito), bem como à saída de recursos (serviços da dívida). Assim, buscando suporte na Tabela 2 e focando no exercício 2013, nota-se que há uma margem de endividamento já que apenas 55,07\% foi comprometido diante da possibilidade de $200 \%$. No entanto, nesse período o serviço da dívida ultrapassou os limites, ainda que com o consentimento do Governo Federal (12,21\%), e as operações de crédito se aproximaram do limite prudencial $(13,6 \%)$. Significa que o Estado deve ficar alerta. Nos demais exercícios essas análises podem ser feitas sem comprometer nenhum indicador.

No Anexo G também se encontram os valores nominais. 
6.2.3 Evolução da dívida contratual interna e externa do estado de Sergipe: 2001-2013

Cabe ressaltar que o endividamento que está sendo avaliado no trabalho não é o endividamento geral do Estado; e sim aquele fruto das operações de crédito e que são a quase totalidade da dívida financeira; excluindo assim os parcelamentos de previdência e de PASEP.

O Anexo $\mathrm{H}$ apresenta os valores da dívida contratual interna e externa, juntamente com os valores desembolsados com o pagamento de amortização, encargos, e o estoque de cada tipo de dívida. Importante salientar que o maior montante de dívida do Estado é interna, cuja amortização representou um acréscimo de 570,34\%, o maior percentual de todos os itens desta tabela, como será demonstrado. Em 2001 foram desembolsados R \$77.905.764, e em $2013 \mathrm{R} \$$ 522.236.265. Os encargos se elevaram em 11,20\% saindo de $\mathrm{R} \$ 121.397 .458$ em 2001 para $\mathrm{R} \$ 134.991 .598$ em 2013. O estoque da dívida interna cresceu em 8,62\%, aumentando de R\$2.112.643.969 em 2001, para R\$ 2.294.761.303 em 2013.

A dívida externa manifestou um decréscimo tanto na amortização como nos encargos do período, atingindo respectivamente os valores de $-82,96 \%$ e $-88,58 \%$. Partiu de uma amortização em 2001 de $\mathrm{R} \$ 25.929 .241$ e chegou a $\mathrm{R} \$ 4.417 .920$ em 2013. Já os encargos caíram de $\mathrm{R} \$ 16.348 .661$ em 2001 para $\mathrm{R} \$ 1.867 .104$ em 2013. Esse comportamento se deve ao encerramento de diversos contratos externos. Isso não é observado com relação ao estoque da dívida externa que teve uma elevação de 53,04\% ao sair de $\mathrm{R} \$ 280.588 .103$ em 2001 para R \$ 429.406.081 em 2013. Isso por conta de um novo contrato externo celebrado sob a denominação de Development Policy Lending- DPL no valor de R \$331.260.000,00.

Em síntese, o somatório das dívidas interna e externa tiveram um volume amortizado no período que correspondeu a um acréscimo de 407,20\% e os encargos uma diminuição de $0,64 \%$. Os pagamentos efetuados no período aumentaram em 174,65\%, saindo de R $\$ 241.581 .124$ em 2001 para R\$ 663.512.887 em 2013. O estoque total da dívida teve acréscimo de 13,83\%, se elevando de $\mathrm{R} \$ 2.393 .232 .072$ em 2001 para $\mathrm{R} \$ 2.724 .167 .384$ em 2013.

Também se encontra o Anexo I os valores nominais.

3.1.4 Comparativo operações de crédito, investimentos, inversões financeiras, despesas correntes, pessoal e encargos sociais 
Conforme o Anexo J demonstra em 2001 as operações de crédito atingiram o valor de $\mathrm{R} \$ 37.645 .614$; e em 2013 esse número se elevou para $\mathrm{R} \$ 751.220 .140$, o que representou um acréscimo de $1.895,51 \%$ em relação a 2001.

As operações de crédito são vastamente empregadas para possibilitar obras e serviços, os quais exigiriam muito tempo para o alcance dos recursos necessários para serem concretizados. Desse modo, o investimento em infraestrutura que impulsiona o desenvolvimento econômico, com melhora da produção e do consumo, requer gasto público, muitas vezes materializado na contratação de dívida (ANDRADE, 2012). O déficit gerado deve ser bem gerenciado a fim de não comprometer nem a capacidade de endividamento e nem de pagamento do ente. Os números constantes do Anexo J nos leva à interpretação de que há um comprometimento grande das receitas estaduais porque estas operações de crédito exigem o pagamento de juros e outros encargos. Assim, a contratação de operações de crédito precisa ser honrada havendo ou não um resultado primário positivo. E cabe aqui a renovação dos comentários feitos na seção 6.2.2.

Em 2003 e 2004 mesmo o Estado descumprindo a meta de Resultado Primário e, portanto, sem possibilidade de contratar operações de crédito, houve liberação de recursos. Isso se deve a pactuações firmadas em exercícios anteriores.

De acordo com o Balanço Geral do Estado de 2006, comprovações da STN dão conta de que o Estado empregou em despesa com ações e serviços públicos de Saúde o percentual de $11,11 \%$, inferior ao limite mínimo exigido que é de $12 \%$. Isso impossibilitou a obtenção do Certificado de Regularidade Previdenciária, e com isso ficou impedido de formalizar convênios com a União, bem como a efetivação de operações de crédito. Vale ressaltar que o resultado primário, de acordo com o PAF também não foi alcançado.

O Estado não poderia contratar operações de crédito se qualquer dos poderes ultrapassasse o limite estabelecido na LRF. Com a ADIN 2.238-5, o Estado ficou liberado para contratar as operações; pois esta suspendeu o art. $9^{\circ}, \S 3^{\circ}$ dentre outros da LRF que conferia liberdade ao Poder Executivo para limitar os valores financeiros dos demais Poderes e do Ministério de acordo com os critérios fixados na lei de diretrizes orçamentária se estes não promovessem a limitação de empenho e movimentação financeira quando se verificasse ao final de um bimestre que a receita não suportaria o cumprimento das metas de resultado primário ou nominal determinadas no Anexo de Metas Fiscais. Com a ADIN o Estado, representado pelo Poder Executivo não é penalizado pelo descumprimento dos outros poderes. E, até o exercício 2013, não houve violação do limite total máximo de $60 \%$. 
Como visto na seção 5.4, apresentada anteriormente, a análise da capacidade de pagamento do Estado é um item importante feito pela STN para fins de contratação de operações de crédito; as quais se agregam às demais exigências para estas operações. Por isso, abaixo se apresentam as classificações obtidas por Sergipe para os últimos seis anos, bem como a metodologia adotada:

Quadro 2 - Classificação da Capacidade de Pagamento do Estado de Sergipe: 2008-2013

\begin{tabular}{|c|c|c|}
\hline Exercício & Classificação & Metodologia \\
\hline 2008 & B & Metodologia antiga \\
\hline 2009 & B & Metodologia antiga \\
\hline 2010 & B & Metodologia antiga \\
\hline 2011 & C & Metodologia antiga \\
\hline 2012 & C3 & Metodologia nova \\
\hline 2013 & C + & \\
\hline
\end{tabular}

Fonte: (SERGIPE, 2015).

O período correspondente ao primeiro mandato do governador Marcelo Déda, que engloba o período de 2008 a 2010, de acordo com a Portaria n. ${ }^{\circ}$ 89/1997, chamada metodologia antiga, o Estado de Sergipe esteve classificado na categoria "B", significando que o resultado primário foi positivo e bastante para saldar todos os encargos das dívidas mobiliária, contratual e flutuante, de origem interna e externa; entretanto insuficiente para honrar com o total da amortização programada, devido o limite de compromissos celebrados contratualmente. Ressaltando que em 2009 e em 2010, as metas de resultado primário estabelecidas segundo o Anexo C que trata do Programa de Ajuste Fiscal, foram negativas em $\mathrm{R}$ \$ 146 e R\$ 329 milhões respectivamente, sendo realizado o valor negativo em milhões de R\$ 140,7, e de R\$ 312 milhões negativos, em 2009 e 2010 sucessivamente. Portanto, superiores as metas.

Em 2011, ainda pela metodologia antiga da Portaria n. ${ }^{\circ}$ 89/1997, o Estado foi classificado em "C", por ter apresentado resultado primário negativo. E a meta era positiva em R\$ 206 milhões, e o valor realizado foi negativo em R\$ 147 milhões. Ainda assim, o Estado contratou operações de crédito num montante de R \$ 377, 39 milhões (valor nominal). Vide no Anexo K- Tabela de Operações de Crédito Contratadas pelo Estado de Sergipe: 2001-2013.

No ano de 2012, já pela metodologia nova da Portaria 306/2012, o Estado se classificou como $\mathrm{C}_{3} *$ por não atender ao indicador de Endividamento e nem ao indicador de 
Serviço da Dívida. Nestes casos, dada a necessidade de prévio pronunciamento favorável do Secretário do Tesouro Nacional, houve contratação de operações de crédito num montante de $\mathrm{R}$ \$ 272,63 milhões.

No ano de 2013 houve um recorde de contratação de operação de crédito, cujo montante foi de $\mathrm{R}$ \$ 751,22 milhões. No entanto, a classificação do Estado foi $\mathrm{C}+$, ou seja, cumpriu com sete dos oito indicadores existentes na Portaria 306/2012, exceto o serviço da dívida.

No Anexo K são destacadas as operações de crédito contratadas no ano, as instituições financeiras, a especificação da dívida, a lei autorizadora, o valor liberado para a especificação e o valor total liberado pela instituição por conta de contratos menores, e o saldo devedor. A Tabela inicia com exercício 2001, e tem uma interrupção nos anos 2003 e 2004, porque a liberação de valores ocorreu por conta de contratação de exercícios anteriores, já que o descumprimento do resultado primário impedia a contratação de operação de crédito. Outra observação é que entre 2006 e 2008 não houve contratação de operações de crédito.

Observando-se atentamente o Anexo K, é possível tirar algumas conclusões: os credores são os mesmos ao longo destes treze anos, desde 2001: CEF, Banco do Brasil, BNDES, Banco do Nordeste. Uma vez que não houve operações de crédito entre 2006 a 2008, apenas liberações de contratos antigos, e em face da crise de 2008; tomou-se como ponto de corte o ano de 2008 e a partir de 2009 resgata se o que acontecia no estado e que provocou a contratação destas operações.

A crise de 2008 que afetou as receitas do FPE de 2008 e 2009, bem como do ICMS, propiciou a contratação de operação de crédito emergencial junto ao BNDES em 2009 e 2010, respectivamente, no montante de $\mathrm{R} \$ 166,21$ milhões (realização de despesas de capital) e R \$ 249,32 milhões (para Programas de Desenvolvimento constante do PPA e leis orçamentárias). Houve investimento em infraestrutura também junto ao BNDES em 2011 e 2012 no montante de $\mathrm{R} \$ 150,63$ milhões e $\mathrm{R} \$ 232,37$ milhões, respectivamente. Também em 2011, o Estado contratou junto a CEF o montante de R\$ 180,00 milhões para Políticas de Desenvolvimento no Estado.

Visando atenuar a pobreza rural foi contratado externamente operações de crédito entre 2009 a 2012, para atender ao Programa de Combate à Pobreza Rural- PCPR. Foi liberado respectivamente $\mathrm{R} \$ 3,10$ milhões (2009); $\mathrm{R}$ \$ 8,05 milhões (2010); $\mathrm{R}$ \$ 5,27 milhões (2011); R \$ 18,13 milhões (2012). 
Em 2013, a lei 7.615, de 13/05/2013 autorizou o Poder Executivo a contratar operações de crédito no valor de $\mathrm{R} \$ 426.791 .548,18$, junto a CEF, voltadas a ampliação da capacidade de investimento e à viabilização do Programa de Apoio ao Investimento dos Estados e Distrito Federal- Proinveste, no contexto da Resolução n. ${ }^{\circ}$ 4.109/12, do Conselho Monetário Nacional. Foi liberado R\$ 257,27 milhões em 2013, sendo que o agente financeiro através do Contrato n. ${ }^{\circ}$ 0395085-63, de 28/06/2013, exige a comprovação da aplicação de pelo menos $80 \%$ deste valor na execução da etapa física da obra e serviços, a fim de que a importância restante seja liberada.

Outro momento do Proinveste em 2013 foi a contratação de operação de crédito no valor de $\mathrm{R} \$ 138,51$ milhões para quitar dívidas do Programa Emergencial de Financiamento, junto ao BNDES.

Ainda em 2013, foi contratado empréstimo externo para pagar outra dívida contratual da Política de Desenvolvimento tomado junto a CEF em 2011, no valor de R\$ 180 milhões. Assim, houve liberação de R\$331.260.000, para o chamado Development Policy Lending- DPL, com a anuência do Governo Federal, de que essa liberação acarretaria no descumprimento do limite de 11,5\% do serviço da dívida em 2013, que foi de 12,21\%.

A síntese da classificação fiscal do estado no segundo mandato de Marcelo Déda reflete uma situação de piora na capacidade de pagamento, o que significa que novas contratações de operações de crédito dependerão da força política conforme se depreende da necessidade do prévio pronunciamento favorável do Secretário do Tesouro Nacional. Ou seja, uma atuação discricionária (art. $9^{\circ}$ Portaria n. ${ }^{o}$ 306/2012).

O investimento realizado em 2001 importou em R\$308.899.219, e em 2013 chegou a $\mathrm{R} \$$ 246.265.625. O período em análise conduz a uma redução de 20,28\%; muito inferior ao crescimento das operações de crédito $(1.895,51 \%)$ já mencionado.

Como demonstra a coluna investimento, o lapso temporal que compreende o ano de 2001 a 2008, mostra um montante de recursos investidos que tanto podem ser próprios, como provenientes de operações de crédito, como fruto de convênios com entes públicos ou privados. Isso é enfatizado entre 2006 e 2008, momento em que não houve operações de crédito. A partir de 2009, embora os investimentos sejam maiores que as operações de crédito, estas se intensificaram e acabaram por se tornar maior que o investimento em 2013; quando foi investido $\mathrm{R} \$ 246.265 .625$, que representa $32,78 \%$ do valor tomado em operações de crédito que somaram $\mathrm{R} \$ 751.220 .140$. 
As inversões financeiras tiveram um decréscimo no período de $74,51 \%$. Apresentaram uma expansão entre 2001 e 2010, com exceção de 2007, e a partir de então diminuíram terminando o ano de 2013 com R\$ 16.320.173. Embora as inversões financeiras possam significar aquisição de imóveis ou bens em utilização, de títulos representativos de capital de empresas, de constituição ou incremento do capital de entidades ou empresas com fins comerciais ou financeiros; em Sergipe elas representam aumento de capital na Administração Indireta do Estado, quais sejam: Deso ${ }^{13}$, Pronese, Sergiportos, Cohidro, Prodase, Cehop.

As despesas correntes tiveram um aumento no período de $96,53 \%$, partindo de 2001 com $\mathrm{R} \$ 3.148 .691 .686$ milhões e terminando em 2013 com $\mathrm{R} \$$ 6.188.209.086. Estas despesas são representadas pelas despesas de custeio, ou seja, a folha de pagamento, e manutenção de serviços públicos; bem como por transferências correntes, onde se tem despesa sem contraprestação direta em bens e serviços; englobando, dentre outros, subvenções sociais e econômicas, pagamento a pensionistas e inativos, contribuições para a previdência social e juros da dívida pública.

As despesas de capital foram incluídas a fim de se verificar o cumprimento da vedação constitucional inserida no art. 167, III, que proíbe a realização de operações de crédito que excedam o montante das despesas de capital, com exceção daquelas autorizadas por créditos suplementares ou especiais com finalidade precisa, devidamente aprovada por maioria absoluta do Poder Legislativo. Deve ser ressaltado que a observância da chamada "regra de ouro", a que se vincula o citado artigo, deve ocorrer na elaboração da LDO e não no momento da realização das despesas de capital e das operações de crédito. Ainda assim, verificamos que a evolução das despesas de capital deu-se em valores superiores às operações de crédito, em todo o período analisado; embora sua elevação tenha sido bem menor que a evolução das operações de crédito. O incremento das despesas de capital foi de 67,84\%, partindo de R\$ 476.762.495 em 2001 para R\$ 800.199.422 em 2013.

As despesas com pessoal e encargos sociais cresceram 148,89\% no período sob análise, partindo de $\mathrm{R} \$$ 1.717.561.106 em 2001, para $\mathrm{R} \$$ 4.274.846.750 em 2013. Por mais que haja o caráter vegetativo deste tipo de despesa de caráter continuado, que aumentam por força de vantagem trabalhistas que são agregadas anualmente, diante do Anexo J elaborado

\footnotetext{
${ }^{13} \mathrm{O}$ maior montante de inversões financeiras foi direcionado para a Deso. As empresas mencionadas receberam inversões financeiras mas não necessariamente em todos os anos do período em estudo. Todas as sociedades de economia mista e empresas públicas do Estado de Sergipe foram transformadas em autarquia e por força de decisão judicial retornaram à natureza jurídica inicial.
} 
essa despesa teve o maior aumento, se excluirmos as operações de crédito. Havendo gasto excessivo com folha de pagamento como consequência haverá pouca disponibilidade de recursos para que o administrador público desenvolva sua atribuição de promover o bem-estar à população, com base nos tributos que arrecada, através da prestação dos serviços essenciais como educação, saúde, segurança, conservação de estradas e trajetos urbanos etc. (ANDRADE, 2012).

Fazendo uma avaliação da variação percentual anual da despesa com pessoal verifica-se que no governo João Alves (2003-2006), o período 2005/2006, apresentou uma elevação de $21,75 \%$ (no período a DCL cresceu 38,14\% e a RCL 9,66\%, segundo o Anexo F); já o intervalo 2003/2004 cresceu 11,31\% (DCL negativa de 0,10\% e RCL 5,52\%). No primeiro governo de Marcelo Déda a maior variação ocorreu entre 2007/2008 que foi de $17,84 \%$ e no período $2008 / 2009$, momento da crise mundial as despesas cresceram $13,70 \%$, e entre 2009/2010 incrementaram 13,18\%. No segundo mandato de Marcelo Déda, o período 2010/2011 apresentou um decréscimo de 21,64\%. No entanto, o período 2011/2012 teve a maior alta de todo o lapso temporal analisado que foi de $38,15 \%$ (veja-se que nesse período a RCL cresceu apenas 0,86\% e a DCL 18,22\%). No período 2012/2013 a despesa de pessoal diminuiu em $3,81 \%$.

Agrupando as informações para o período de maior endividamento do estado, tem se que entre 2001 e 2008 a despesa com pessoal se elevou em $85,76 \%$, enquanto que a RCL foi incrementada em 69,93\% e a DCL em -52,38\%. Entre 2009 e 2013, a despesa total com pessoal aumentou 17,84\%; ainda assim acima da RCL que cresceu 10,64\% e a DCL que foi incrementada em 129,82\%. Ainda que se considere o lapso temporal dos 13 anos de implantação da LRF, a despesa com pessoal se ampliou em 148,89\%, diante de um crescimento da RCL de $86,79 \%$, e a DCL de $29,37 \%$.

No Anexo L tem-se os valores nominais.

\subsubsection{Desempenho do PIB de Sergipe: 2001-2012}

Ao se falar do comportamento das finanças públicas não se pode esquecer que elas estão atreladas ao desempenho da economia, pois só assim os recursos suficientes serão canalizados para o atendimento das necessidades. Desse modo, analisar a trajetória do PIB 
diante das políticas governamentais tanto federal como estadual permite projetar expectativas mais realistas.

O Anexo M apresenta a evolução do PIB do Brasil, das Regiões e os Estados que compõem a Região Nordeste, a fim de destacar o Estado de Sergipe.

Os dados do Produto Interno Bruto do Brasil e das Unidades Federadas, bem como o Produto Interno Bruto per capita correspondente e a Participação das Unidades Federadas no Produto Interno Bruto elaborados pelo IBGE para o exercício 2013 só serão divulgados em dezembro/2015; por isso nesse ponto, tudo o que se refere ao PIB será estudado com limitação ao exercício de 2012.

O crescimento do PIB do Brasil foi de 84,61\%. A Região Norte atingiu uma elevação de 104,44\%; a Região Nordeste cresceu 90,71\% e a Região centro-oeste foi o destaque do período ao alcançar uma elevação no PIB de 151,36\%. No entanto, o aumento da Região Sudeste foi $78,37 \%$ e a região Sul foi a que menos cresceu $67,85 \%$. Isso demonstra ainda a preponderância das regiões sul e sudeste no PIB do país. O destaque nordestino ficou para o Estado do Maranhão que cresceu 187,93\%. Já Sergipe atingiu 70,88\%, inferior tanto à própria região, como ao crescimento nacional. O comportamento da economia se refletirá nas finanças públicas. Como dito no início da exposição sobre Sergipe, o Estado conta com um setor minero-químico que é fortemente influenciado pelo mercado internacional, e que, portanto, ainda vem se recuperando da crise de 2008. Mas, ainda assim, recordando o Anexo D, o ICMS cresceu 104,39\% (mesmo com atualização para 2013 e não 2012), demonstrando um bom desempenho e a RCL 86,79\%.

Nota-se que tanto a região Nordeste como Sergipe tiveram um impulso crescente no valor do PIB a partir de 2004, devido à expansão econômica devido a expansão do consumo, e que é abalada com a crise de 2008. O progresso foi impulsionado por ação do governo federal com transferências no âmbito do programa Bolsa Família e dos benefícios de prestação continuada. Mesmo havendo a crise a região nordeste sofreu menos impactos que as demais, uma vez que sua produção industrial é menos dependente do mercado externo e do crédito ao consumo. (BANCO CENTRAL DO BRASIL, 2009).

Está perceptível o pouco avanço do PIB entre 2008 e 2009, momento da crise financeira internacional, que foi de $2,51 \%$ e posteriormente, ainda mais reduzido entre 2011 e 2012, como resultado da intensificação da crise na Europa, que foi de 0,45\%. Em comparação com Sergipe o PIB no período 2008/2009 apresentou um decréscimo de 2,99\%, e no período de 2011/2012 uma elevação de 0,63\%, superior ao crescimento nacional. 
No Anexo $\mathrm{N}$ também se encontram os valores nominais.

Como sequência da análise do PIB será verificada a participação per capita que nos dá uma melhor noção da realidade de como a grandeza PIB e população se alteram no tempo, conforme o desenvolvimento do Estado. Posteriormente será vista a participação relativa das unidades federadas.

A evolução do Produto Interno Bruto per capita Brasil, Regiões e Estados do Nordeste a preço de mercado no período considerado (valor atualizado IPCA dez/2013) é apresentado no Anexo O, mostrando que o Brasil cresceu 64,08\% e que as Regiões Norte, Nordeste, Sudeste, Sul e Centro-Oeste cresceram respectivamente, 65,69\%, 70,97\%, 60,73\%, $54,00 \%$ e $107,12 \%$. Novamente o destaque para o Centro-Oeste demonstra a obtenção do maior PIB per capita nacional. Na avaliação entre os Estados do Nordeste, novamente o Maranhão se destaca com 145,77\% e Sergipe tem a última colocação da Região Nordeste, com 47,13\%, como também apresentou um aumento menor que o alcançado nacionalmente.

$\mathrm{Na}$ avaliação do comportamento do PIB per capita do Brasil no momento da crise financeira internacional entre 2008/2009, que foi de elevação de 1,52\% com o período posterior de intensificação da crise europeia, verifica-se que 2011/2012, houve um crescimento negativo de 0,36\%. O Estado de Sergipe foi afetado tanto em 2008/2009 quando seu PIB per capita diminuiu em 3,97\%, como em 2011/2012 quando decresceu 0,37\%. Em ambos os momentos mais do que o registrado para o país.

No Anexo P têm-se valores nominais.

O Anexo Q mostra a participação das unidades federadas na composição do PIB. A participação do Nordeste no PIB nacional no período sob análise fica entre 12,6 e 13,6, praticamente constante, exceto por aproximação matemática em 2009 e 2012 que conduziria a uma pequena elevação; sendo que a participação de Sergipe se manteve constante durante todo esse tempo em 0,6. O desempenho de Sergipe se igualou ao do Piauí, mas o valor de 0,6 para este Estado representou uma evolução a partir de 2008 e mantido constante por 4 anos. No caso de Sergipe esse valor perdura por 13 anos. Ou seja, a economia estadual precisa de um incentivo para se desenvolver; o que pode ser obtido através de obras que sejam estruturantes.

A seção seguinte vem analisar os números alcançados pelos indicadores de Sergipe. 
Uma vez que já foi tratado do antecessor da LRF, o Programa de Ajuste FiscalPAF, o comportamento das principais receitas, das dívidas e do PIB, cumpre verificar o que de fato tem acontecido em relação a observância da LRF no Estado, e o seu desdobramento.

A construção de uma tabela para explicitar o cumprimento dos indicadores constantes da LRF no período de 2001 a 2013, conduziu a elaboração da Tabela 2 abaixo. Nesse lapso temporal o Estado foi governando por Albano Franco: 1999- 2002 (reeleição); João Alves: 2003-2006 (eleição); Marcelo Déda: 2007-2010 (eleição); Marcelo Déda: 20112013 (reeleição/falecimento); Jackson Barreto: 2013-2014 (vice governador assumindo). A citada tabela apresenta doze indicadores: Gasto total com pessoal; Gasto com pessoal do Poder Executivo; Gasto com pessoal do Poder Judiciário; Gasto com pessoal do Poder Legislativo (gastos com Pessoal da Assembleia Legislativa e Gastos com Pessoal do Tribunal de Contas); Gasto com pessoal do Ministério Público; Dívida Consolidada Líquida; Serviço da Dívida, Garantia de Valores; Operações de Crédito Internas e Externas; Operações de Crédito por Antecipação de Receita.

Em relação ao indicador gasto total com pessoal, o Estado obedeceu ao limite máximo de $60 \%$, e por isso não estaria impedido de contratar operações de crédito conforme previsto no art. $23, \S 3^{\circ}$ LRF. Ocorre que ultrapassou o limite prudencial em 2001, 2003, 2012 e 2013 , quando atingiu respectivamente $58,25 \% ; 59,21 \% ; 58,05 \% ; 58,86 \%$, quando deveria ter se limitado a $57 \%$.

O indicador gasto com pessoal do Poder Executivo apresenta o Poder Executivo violando o limite prudencial em cinco exercícios 2001, 2003, 2011, 2012, 2013, com participação percentual nessa ordem de 47,39\%; 47,50\%; 46,76\%; 48,25\% e 48,74\% quando na verdade deveria gastar apenas $46,55 \%$. Esse percentual de gasto tem inviabilizado o reconhecimento de direitos que redunde num aumento de despesa, ou mesmo a concessão de uma remuneração digna aos servidores públicos, ligados ao Poder Executivo; já que pelo art. 22, parágrafo único da LRF fica vedada concessão de vantagem, aumento, reajuste ou adequação de remuneração a qualquer título, exceto o decorrente de sentença judicial, ou determinação legal ou contratual, com a obediência às disposições constitucionais. Também impede alteração de estrutura de carreira, ou provimento de cargo público, dentre outros. Mas, o curioso em Sergipe é que o Poder Executivo tem assumido a folha de inativo de pensionistas e aposentados dos demais poderes. Com isso, não há indisposição política, mas também 
impede que os servidores públicos deste poder tenham expectativas poder concretizar seus pleitos.

O indicador gasto com pessoal do Poder judiciário aponta que este Poder é o único que cumpriu tanto o limite máximo como o limite prudencial no intervalo do estudo.

O indicador gasto com pessoal do Poder Legislativo esteve acima não só do limite prudencial de 2,85\% nos anos 2010, 2012 e 2013; como esteve acima do limite máximo de $3 \%$ em todos os demais exercícios; chegando a 5,49\% em 2004. Isso é fruto do descumprimento por parte dos gastos com pessoal tanto no Tribunal de Contas como na Assembleia Legislativa. Somente no ano de 2012, a Assembleia Legislativa esteve abaixo do limite prudencial de 1,75\%; estando acima do limite prudencial em 2008, 2011 e 2013; e totalmente acima do limite máximo de 1,84\%, de 2001 a 2007; 2009 e 2010.

A situação em relação ao gasto com pessoal do Tribunal de Contas do Estado (TCE) merece uma ressalva especial. Somente no ano de 2010, o TCE obedeceu ao limite prudencial de 1,10\%; e em 2013 alcançou o teto máximo de 1,16\%. Nos demais onze anos, houve um excesso que supera em muito o limite máximo, como observado no ano de 2004 quando chegou a 1,92\%. No entanto, a Decisão TC 16779, de 28/02/2008, do Pleno do Tribunal, produzida nos autos do processo TC- 000081/2008, estabelece que

para os fins do cálculo dos limites previstos na Lei de Responsabilidade Fiscal de despesas com pessoal, o valor correspondente ao Imposto de Renda Retido na Fonte (IRRF), incidente sobre a remuneração, subsídios e proventos dos servidores públicos Estaduais e Municipais, sob a jurisdição deste Tribunal, não deverá ser considerado no cômputo da receita corrente líquida e nem no somatório da despesa total com pessoal dos Poderes e Órgãos Públicos (TCE/SE, 2008).

Com esse entendimento, o TCE, durante o período sob análise, não estaria acima dos limites da LRF. A Decisão TC supramencionada ainda informa que este entendimento tem sido praticado inclusive por alguns Executivos Estaduais, como o Rio Grande do Sul, Goiás e Paraná. Esta matéria está sob apreciação do Supremo Tribunal Federal, existindo Ação Direta de Inconstitucionalidade - ADI n. ${ }^{\circ} 3889-R O$, autuada no dia 26/04/2007, sem ter até o momento um parecer contrário às teses argumentadas por diferentes Tribunais de Contas, a exemplo de Rio Grande do Sul, Rondônia, Espírito Santo, Pará, Paraíba, Maranhão, Paraná, Roraima, e Rio Grande do Norte. (TCE/SE, 2008). 
O gasto com pessoal do Ministério Público esteve acima do limite máximo de 2,00\% no intervalo 2004 a 2006, e acima do limite prudencial de 1,90\% em 2007. Nos outros exercícios manteve-se abaixo do limite prudencial.

O curioso no tema da despesa com pessoal e o respectivo limite legal é que compete ao Poder Legislativo seja diretamente ou com o assessoramento dos Tribunais de Contas, e o sistema interno de cada Poder e do Ministério Público a fiscalização do cumprimento da LRF; havendo exigência do retorno aos limites legais a ser imposto na tarefa da fiscalização. Diante da Tabela 2 apresentada com os indicadores para o Estado de Sergipe, entendo que o inciso III do art. 59 da LRF fica fragilizado, para o exercício de uma atuação rigorosa, uma vez que o Tribunal de Contas com o parecer supracitado autoriza que todos a ele submetido descumpra a LRF. E o parecer também vale para descumprimento por parte do Ministério Público do Estado, que descumpriu a Lei em 4 períodos.

No que se refere à Dívida Consolidada Líquida, o Estado vem cumprindo o limite de $200 \%$ com muita folga durante todo o período de análise. Atingiu o menor índice em 2008 que foi de 21,84\%; e o maior em 2001, quando chegou a 77,85\%. Esta análise deve ser associada aos comentários realizados na seção 6. 2.2.

No tocante ao serviço da dívida, o governo estadual vinha cumprindo o limite máximo de 11,5\% até que em 2013 atingiu 12,21\%. No entanto, para a realização desse montante houve anuência do governo federal, para a tomada do empréstimo externo chamado Development Policy Lending- DPL, para pagar outra dívida contratual da Política de Desenvolvimento (quitar a dívida junto a CEF de R 180 milhões tomados em 2011). Houve liberação de R \$ 331.260.000. Desse modo, não há que se falar em descumprimento.

Não houve garantia de valores no período considerado, o qual tem limite máximo de $22 \%$. Isto porque os avais concedidos aos beneficiários (Cehop, Cohidro, Deso, Ipes) estão incorporados na dívida do Estado, constando assim do Balanço Geral do Estado.

No que se refere às operações de crédito interna e externa que apresenta o limite prudencial de 14,4\% e o máximo de 16\%, o Estado vem obedecendo às limitações legais, e entre os anos 2006 a 2008 não houve contratação, conforme explicado na seção 6.2.4, comparativo das operações de crédito, investimentos, inversões financeiras, despesas correntes, pessoal e encargos sociais.

O último indicador são as operações de crédito por antecipação de receita orçamentária que apresentam o limite máximo de 7\%. Como se sabe esse tipo de operação deve ser realizada para suprimento de caixa, devendo ser pago no exercício em que foi 
contratada. Portanto, o tempo para pagamento é muito exíguo, tornando-se desinteressante, já que há a incidência de encargos. Assim, o Estado optou por não realizar tais operações no período analisado.

O Estado de Sergipe está com classificação da capacidade de pagamento em C, e com isso as contratações das operações de crédito têm contado com o parecer político do Secretário do Tesouro Nacional. 
Tabela 2- Indicadores de Sergipe para a Lei de Responsabilidade Fiscal (LRF): 2001-2013

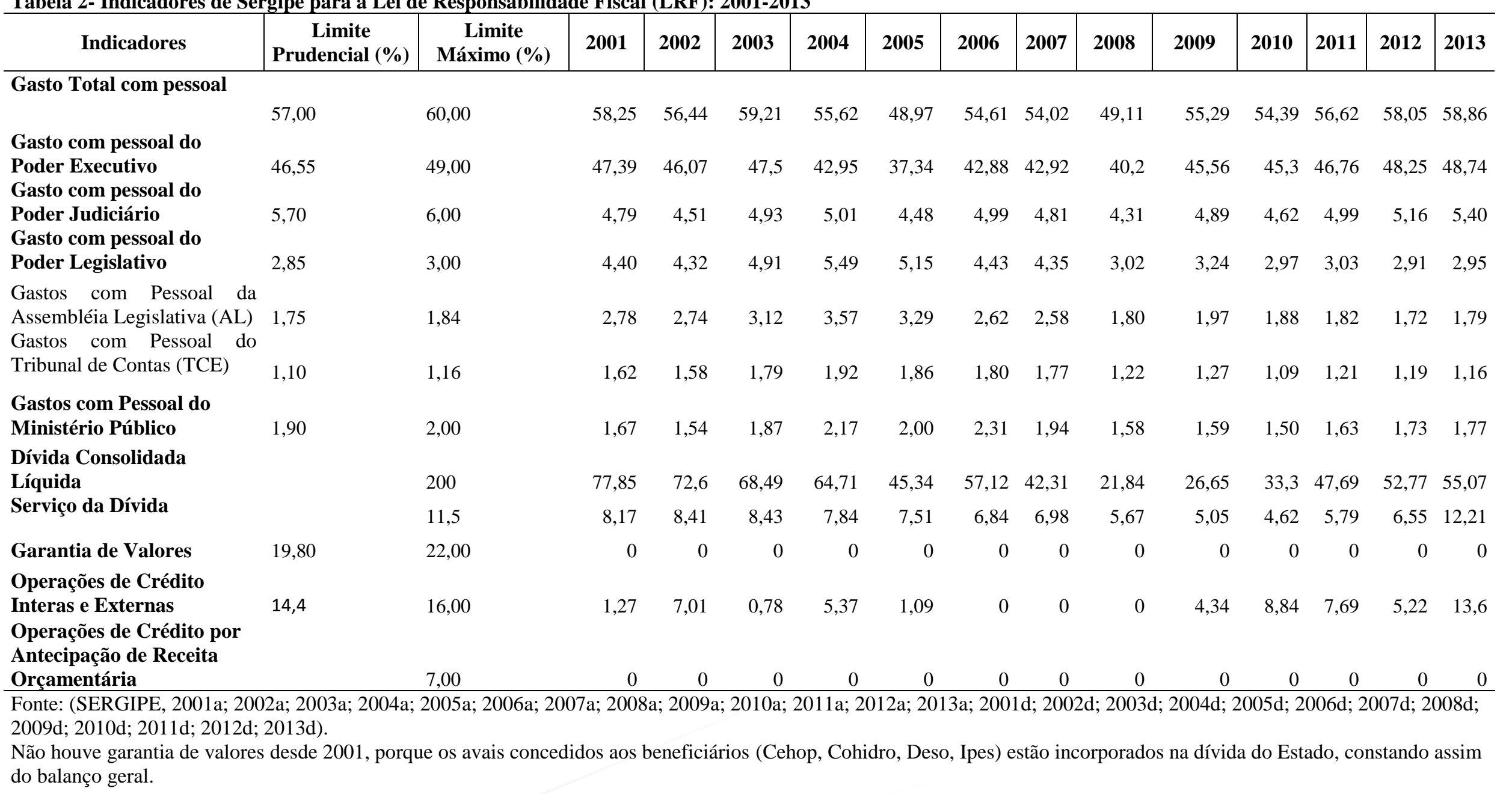




\section{Considerações finais.}

O presente trabalho pretendeu trazer os números de Sergipe referentes aos indicadores da Lei de Responsabilidade Fiscal, avaliando o comportamento do cumprimento desta Lei, no lapso temporal desde a sua implantação, ou seja, 2001 até 2013.

Como a situação financeira dos entes federados não permitia o equilíbrio das contas, após 1995 se iniciaram as medidas para proporcionar esse ajuste. Para que o Estado de Sergipe conseguisse aderir ao Programa de Ajuste Fiscal (PAF) autorizado pela Lei 9496/97, foi imposta uma serie de medidas conservadoras condizentes com uma função de governo estabilizadora. O governador da época Albano Branco providenciou em 1997, a venda da Energipe, que se pode dizer foi o sinal do contrato; saneou o Banco do Estado de SergipeBanese; patrocinou um Programa de Desligamento Voluntário (PDV). Além disso, foi impedido de emitir novos títulos públicos a partir daí, mas através do PAF conseguiu renegociar dívidas de títulos mobiliários emitidos pelo governo de João Alves (15/03/1991 a 01/01/1995); e que representaram o maior montante da renegociação. Lembrando que os valores originais da dívida em títulos importaram em $\mathrm{R} \$ 206,13$ milhões; de uma dívida total de $\mathrm{R} \$ 313,93$ milhões (desse montante está excluída a amortização extraordinária do valor de privatização pela venda da Energipe avaliada em $\mathrm{R} \$ 41,23$ milhões).

Como o cumprimento das metas do PAF são impositivas, em especial as metas $1 \mathrm{e}$ 2 , respectivamente dívida financeira em relação a receita líquida real em valor menor ou igual a 1; e a busca pelo resultado primário pactuado, isso possibilitou que a inserção de novas exigências para o cumprimento das metas dos indicadores da LRF fosse feita sem impactos. Inclusive a relação dívida financeira/RLR no valor menor ou igual a 1 é mais rigorosa no PAF do que a relação determinada pela $\mathrm{LRF}$ de $\mathrm{DCL} / \mathrm{RCL}=2$ (parâmetro que atendeu às necessidades dos entes federados mais desenvolvidos). Mais ainda, o resultado primário no PAF precisa ser buscado para atingir a meta estipulada. Na LRF, o resultado primário só precisa ser informado, em função do que foi realizado; não existe meta a ser perseguida. Cabe mencionar aqui que diante da necessidade do aperfeiçoamento e melhora da gestão, e a responsabilização trazida pela LRF, o Senado Federal não impôs limite para as dívidas da União; mas tão somente para Estados, Distrito Federal e municípios. É o que está claramente escrito tanto na Resolução 40/2001, como na Resolução 43/2001. 
Mesmo com o cumprimento das metas do Programa de Ajuste Fiscal, o que se tem visto é um aumento do endividamento do Estado, com garantia da União, em especial a partir de 2009. No primeiro mandato do governador Marcelo Déda, o Estado tinha uma boa classificação da capacidade de pagamento "B", a qual foi piorada no início do segundo mandato e assim se manteve entre 2011 e 2013.

Em termos de evolução da DCL em relação a RCL pode-se verificar a existência de 02 períodos: a) um que ocupa o lapso temporal 2001 a 2008, exceto, o ano de 2006; e nesse período houve uma diminuição na dívida em 52,38\%, em relação ao crescimento de 69,93\% da RCL; b) entre 2009 e 2013 a DCL se elevou em 129,82\% ao sair de R\$1.330.828.574 em 2009 para R\$ 2.978.711.956 em 2013. Já a RCL teve um modesto incremento de 10,64\% ao sair de $\mathrm{R} \$$ 4.992.835.655 em 2009 para $\mathrm{R} \$$ 5.524.274.805. Não tem como um aumento de receita tão baixo suportar uma elevação de dívida nesta proporção.

Como o estado foi classificado na capacidade de pagamento como "C" entre 2011 e 2013 significa que todas as operações de crédito precisaram do pronunciamento do Secretário do Tesouro Nacional. E nos anos do estudo, por se ter uma sigla partidária igual ou coligada, o critério político se sobrepôs ao critério técnico. Desse modo, por mais endividado que o estado esteja, ainda consegue contrair novos empréstimos com base na camaradagem. Infelizmente, o governo toma empréstimo para quitar outros empréstimos, como fez em 2013, ao contratar operações de crédito externo de $\mathrm{R} \$ 331,26$ milhões para quitar o empréstimo obtido junto a CEF de R $\$ 180$ milhões em 2011.

O Estado não pode emitir títulos da divida pública até 2027, de acordo com o contrato assinado no PAF. Com isso sua fonte de receita fica adstrita as suas principais receitas: o FPE, ICMS; ou a contratação de operações de crédito, que como já foi dito, já está intensificada nestes últimos anos, o que fatalmente conduzirá o Estado à inadimplência. O FPE sempre representou mais de $50 \%$ da receita estadual e o ICMS em torno de $45 \%$. As tabelas colacionadas ao presente trabalho mostraram que as receitas do FPE tem diminuído paulatinamente por conta da extrafiscalidade de um de seus componentes o IPI, aproximando -se ao arrecadado pelo ICMS. Então, as projeções de aumento de despesa precisam estar concatenadas com a realidade, bem como com os compromissos assumidos com essas receitas.

Isto porque, nas lições de Afonso (2014a), descortina-se um quadro no qual o ICMS está obsoleto e o Fundo de Participação dos Estados (FPE) esvaziado, diante do aumento progressivo das dívidas. E como já foi demonstrado no Anexo D, como também 
apontado acima, a RCL, que é a base da LRF não tem crescido na proporção da despesa. Assim, não resolve tentar aumentar a carga tributária vinculada ao ICMS e muito menos contrair mais dívidas. Seguindo a linha de Afonso (2014a) a proposta é de melhora da produtividade do gasto e a modernização da gestão.

Afonso (2014a) apresenta algumas sugestões de modernização da gestão tais como a modificação dos sistemas integrados a fim de servir aos novos padrões contábeis; a evolução da gestão financeira e o aprimoramento da transparência fiscal. O citado autor aconselha que se invista nas fazendas estaduais para reparar os atrasos em termos de administração tributária, acrescentando além da melhora em sistemas a necessidade de ampliação e de capacitação de pessoal especializado, e plano de carreira. Em relação às outras receitas onde se incluem as transferências federais (FPE, FUNDEB, royalties) a recomendação é de um monitoramento minucioso. No tocante a eficiência de gestão indica a produção de sistemas contínuos e seguro para estimar a qualidade do gasto; dentre outras orientações.

Cabe aproveitar a oportunidade e mencionar que o Brasil precisa de uma reforma tributária abrangente e urgente, com revisão não só dos tributos existentes como da repartição de receitas e atribuições. Como auditora tributária do Estado de Sergipe tenho presenciado as distorções que nosso sistema tributário tem proporcionado à produtividade e à competitividade nacional, já que a carga tributária nacional encarece a produção no mercado doméstico prejudica o emprego e a produção, afora bloquear o acesso ao mercado internacional.

A relação entre contratações de operações de crédito e os investimentos realizados no território sergipano no período analisado não é proporcional; mas, ao contrário, muito destoante. Entre 2001 e 2013, as operações de crédito evoluíram 1.895,51\%; enquanto o investimento declinou 20,28\%. Os investimentos em 2013 importaram em $\mathrm{R} \$ 246.265 .625$, o que representa somente $32,78 \%$ do valor tomado em operações de crédito que somaram $\mathrm{R} \$$ 751.220.140. As inversões financeiras do período foram insignificantes em relação ao montante de operações de crédito $\mathrm{R} \$ 16.320 .173$. Pelo bem de nossa população, espera-se que esse dinheiro esteja guardado para uso no tempo devido, já que as operações de crédito tem destinação específica para investimentos e inversões financeiras. Quando se subdivide o lapso temporal nos dois subperíodos já informados anteriormente, ou seja, entre 2001 e 2008 e entre 2009 e 2013, obtém-se o percentual de $-100 \%$ de operações de crédito (2001/2008) e 246,45\% (2009/2013). Em relação ao investimento há diminuição de 38,39\% para o período 2001/2008 e o decréscimo de 23,05\% para o intervalo 2009/2013. Esse panorama quer significar que o 
endividamento contraído não se converteu em investimento, e o que é pior, foi direcionado para gastos correntes, incluindo pessoal; como foi visto na seção 6.2.4.

É bom ressaltar que o montante de $\mathrm{R} \$ 257.274 .928$, referente a primeira parcela de um total de $\mathrm{R} \$ 428.791 .548,18$, liberado para o Proinveste pela CEF, por conta do Contrato n. ${ }^{\circ}$ 0395085-63, de 28/06/2013, tem como exigência do agente financeiro a comprovação de no mínimo $80 \%$ da execução da etapa física da obra e serviços a fim de que o restante do valor pactuado seja liberado. Há um relatório de acompanhamento da realização da obra. O curioso nessa operação de crédito é que com tal operação há um reforço ao endividamento estadual para a realização de obras que, embora sejam necessárias, não são estruturantes a ponto de repercutir positivamente para o futuro da economia, o desenvolvimento a longo prazo e na arrecadação estadual. Pode-se citar a recuperação do sistema viário do Centro administrativo Governador Augusto Franco; urbanização da Comunidade Malvina no Bairro Aeroporto (Recanto da Paz), em Aracaju; dentre outros.

Cumpre acrescentar que a vinculação da receita dos fundos constitucionais ao pagamento de dívidas; bem como às receitas próprias assegura não só a adimplência da dívida, como o endividamento é facilitado devido a existência desta garantia. Mas, a assunção de dívidas incomensurável repercute num profundo comprometimento quanto a qualidade dos serviços públicos futuros a serem prestados, já que restará pouco para ser investido nas necessidades dos cidadãos. E ao menor sinal de inadimplência, haverá retenção compulsória do valor devido.

Entre 2001 e 2013, o maior endividamento do estado é interno e principalmente com o Banco do Brasil e o BNDES, que juntos somam 64,53\% das operações de crédito contratadas em 2013. E mesmo na década de 80 até o PAF, os montantes de empréstimos internos sempre foram maiores que os externos.

$\mathrm{Na}$ avaliação do cumprimento dos indicadores preconizados pela LRF percebe-se que o indicador gasto com despesa de pessoal, foi observado pelo Poder Judiciário em todo o lapso temporal avaliado. O Poder Legislativo, ao contrário descumpriu em todo o período, tendo o Tribunal de Contas e a Assembleia Legislativa obedecido em apenas um exercício cada. Como mencionado, existe a Decisão do Pleno do Tribunal de Contas n. ${ }^{\circ}$ 16779, de 28/02/2008, que modifica a forma de cálculo da RCL, e que está sob apreciação do STF, com ADIN n. ${ }^{\circ}$ 3889-RO autuada desde 26/04/2007. Mas até então, o órgão fiscalizador da LRF autoriza que todos os demais Poderes e órgãos também descumpram a lei. O Poder Executivo assim como o Ministério Público descumpriu a LRF em 4 exercícios cada. A violação ao 
limite prudencial impede dentre outras previsões a concessão de vantagem, aumento ou reajuste aos servidores públicos, conforme previsão do art. 22, parágrafo único, I, da LRF. Todavia, como o limite total máximo de $60 \%$ ainda não foi atingido, o estado de Sergipe

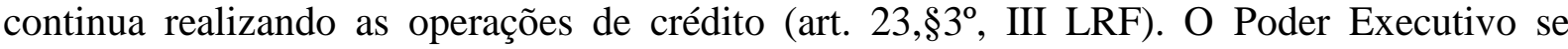
encontra acima do limite prudencial de 46,55\%, por conta de despesa com pessoal, por abranger despesas com pessoal inativo pensionista e aposentado que não pertence ao seu poder, conforme mencionado na seção 6.2.6, e não há demonstração de que esse quadro irá mudar. Ou seja, a LRF traz doze indicadores, sendo sete voltados a controle de despesa com pessoal e apenas um Poder está cumprindo os ditames desta lei nacional.

Considerando as despesas de pessoal durante o lapso temporal dos 13 anos de implantação da LRF, a despesa com pessoal se ampliou em 148,89\%, diante de um crescimento da RCL de 86,79\%, e a DCL de 29,37\%. Agora, porém, agrupando as informações para o período de maior endividamento do estado, tem se que entre 2001 e 2008 a despesa com pessoal se elevou em $85,76 \%$, enquanto que a RCL foi incrementada em $69,93 \%$ e a DCL em -52,38\%. Entre 2009 e 2013, a despesa total com pessoal aumentou 17,84\%; ainda assim acima da RCL que cresceu $10,64 \%$ e a DCL que foi incrementada em 129,82\%. Isto leva a uma situação insustentável a exigir medidas imediatas. A alternativa viável ao governo estadual é encabeçar a função estabilizadora prescrita por Musgrave R. e Musgrave P. (1989), para garantir estabilidade das contas públicas e o equilíbrio financeiro do governo. Isso significa tomar medidas conservadoras para diminuição das despesas correntes.

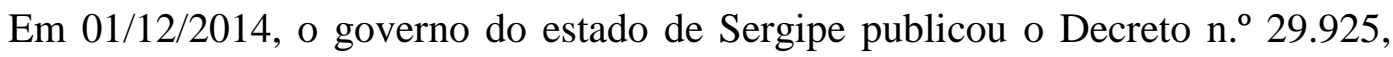
estabelecendo medidas para a gestão e controle de despesas com pessoal no âmbito da Administração Pública estadual do Poder Executivo considerando a frustração de receita do FPE e a obediência à LRF. Assim, as despesas adicionais de pessoal ficaram impedidas. Ou seja, proibiu-se a concessão de hora extra, a criação de cargos em comissões de trabalho e de gratificação de caráter discricionário.

No mesmo diapasão do Decreto de controle de gasto por parte da Administração Pública Direta do Poder Executivo, o Decreto, S/N de 01/12/2014 exonera os cargos em comissão de natureza simples ou especial da Administração Pública Direta, excetuando-se os servidores titulares de cargo efetivo, os Secretários de Estado, os Subsecretários de Estado, os Secretários Adjuntos e o Ouvidor-Geral do Estado.

A medida em si é excelente para o controle de gastos. No entanto, pelo que já foi mencionado anteriormente tem-se que: o Poder Executivo tem assumido a conta dos inativos 
dos demais poderes, sem ter coragem de devolvê-los aos seus respectivos poderes; também ainda não tem uma política de concurso público, e muitos serviços públicos estão sendo fornecidos por pessoas em cargo em comissão ou por empresas prestadoras de serviços. O que se espera é que de fato essas medidas representem uma mudança no perfil da gestão, e que seja complementada pela modernização da gestão.

Pelo visto na Tabela 2, embora a maior despesa de pessoal, face ao quantitativo de servidores, seja do Poder Executivo, seria razoável que os demais Poderes acompanhassem, pois um estado equilibrado financeiramente facilita a vida de todos; além de ser uma previsão da LRF no art. 9, onde consta a limitação de empenho por cada Poder caso haja previsão de frustração da receita após um bimestre.

A LRF que veio reforçar a responsabilidade do gestor público, apresentando limites quanto aos indicadores operações de crédito e quanto aos limites da dívida; e embora se tenha revelado o endividamento estadual, estes indicadores foram cumpridos exceto no ano 2013, em relação ao serviço da dívida; por conta da contratação de operação de crédito externo com aval da União, e já comentado para quitar dívidas anteriores.

A relação entre DCL e RCL é pequena, de modo que abre espaço para um grande para endividamento já que o limite é de $200 \%$. O maior valor atingido pelo estado foi de 77,87\% em 2001. Em 2013, foi de 55,07\%.

Os demais indicadores da LRF tais como garantia de valores e, operações de crédito por antecipação de receita orçamentária foram observadas dentro dos parâmetros da lei uma vez que a garantia de valor não foi utilizada porque as dívidas dos possíveis beneficiários se encontram inseridas no Balanço Geral do Estado. Quanto a ARO, o estado não se serviu deste instrumento por não ser interessante tomar empréstimo de curto prazo, já que o pagamento do principal e acessório deve ser efetuado no mesmo exercício, preterivelmente até $10 / 12$.

O PIB de Sergipe no período $2001 / 2013$ foi de $70,88 \%$, o menor da região Nordeste (90,71\%), e menor que o do Brasil (84,61\%). No momento da crise 2008/2009 e em 2011/2012, o PIB estadual declinou 2,99\% e se elevou 0,63\% respectivamente. Já o país apresentou avançou respectivamente $2,51 \%$ e $0,45 \%$. Esse panorama influencia a economia estadual e consequentemente a arrecadação dos tributos. Na evolução do PIB per capita, enquanto o Nordeste cresce 70,97\%, e o Brasil 64,08; Sergipe atinge 47,13\%. Frise-se que com esse índice, o estado atingiu a última colocação da região. O PIB per capita do estado declinou 3,97\% no período 2008/2009; e 0,37\% entre 2011/2012. O PIB per capita nacional 
no mesmo período se elevou 1,52\% entre 2008/2009 e decaiu 0,36\% entre 2011/2012. No que diz respeito a participação de Sergipe no PIB nacional, o estado mantém a mesmo posição há 13 anos com 0,4. A participação da região Nordeste oscila entre 12,6 e 13,6. Ou seja, a economia estadual precisa de um incentivo para se desenvolver; o que pode ser obtido através de obras que sejam estruturantes.

Assim, ante o exposto, o impacto proporcionado pela implantação da LRF no Estado de Sergipe não foi negativo, embora o indicador gasto de pessoal, com exceção do Poder Judiciário, não tenha sido cumprido na íntegra, precisando o esforço dos gestores de todos os Poderes não enquadrados na norma, e que representam 50\% dos indicadores, já que 6 dos 12 indicadores, estão fora dos padrões. A contribuição do PAF foi positiva para o Estado de Sergipe, sendo totalmente diferente do que aconteceu com o Estado de Minas Gerais que segundo Jayme Jr, Reis e Romero (2006) foi fortemente prejudicado justamente pelo acordo.

O cumprimento aos ditames da LRF suscita a possibilidade de ocorrência de trade off em razão de que a obediência à lei de responsabilidade fiscal, e a consequente delimitação de gasto poderia reprimir as políticas delineadas pelos governantes para combater crises econômicas. Isso é o que alerta Giuberti (2005). Mas essa situação ainda não foi experimentada pelo governo sergipano.

Embora a experimentação da LRF tenha todas as nuances acima relatadas, não se pode deixar de afirmar que a LRF representou uma mudança de cultura no Estado; tanto que no Decreto mais recente de contenção de despesas o fundamento é a obediência à lei de responsabilidade fiscal. Então, o lema e a experimentação da transparência e da responsabilidade impressos pela lei ainda estão sendo sedimentados paulatinamente a fim de que a gestão tenha maior credibilidade, e que o gestor de recursos públicos possa de fato se reconhecer adequadamente nessa tarefa. 


\section{REFERÊNCIAS}

BANCO CENTRAL DO BRASIL. Boletim regional. 2009. Brasília. Disponível em: <http://www.bcb.gov.br/economiaefinanças/boletimregional>. Acesso em: 01 fev. $201 \underline{\text { s. }}$

BRASIL. Ministério da Fazenda. Secretara do Tesouro Nacional. Lei Complementar $\mathbf{n}^{\mathbf{o}}$ 101, de 04 de maio de 2000. Estabelece normas de finanças públicas voltadas para a responsabilidade na gestão fiscal e dá outras providências. Disponível em: < http://www.stn.fazenda.gov.br> Acesso em: 15 maio de 2014.

BRASIL. Ministério da Fazenda. Secretaria do Tesouro Nacional. Resolução 43, de 2001 do Senado Federal, que dispõe sobre as operações de crédito interno e externo dos Estados, do Distrito Federal e dos Municípios, inclusive concessão de garantias, seus limites e condições de autorização.

BRASIL. Ministério da Fazenda. Secretaria do Tesouro Nacional. Senado Federal. Resolução 40, de 09 de abril de 2002. Dispõe sobre as operações de crédito interno e externo dos Estados, do Distrito Federal e dos Municípios, inclusive concessão de garantias, seus limites e condições de autorização. Disponível em: <www.stn.fazenda.gov.br〉 Acesso em: 15 de maio de 2014.

BRASIL. Secretaria do Tesouro Nacional (STN). Lei de Responsabilidade Fiscal Cartilha. Disponível em <http://www.stn.fazenda.gov.br>. Acesso em: 15 de maio de 2014.

CEPLAN. Consultoria Econômica e Planejamento. Sergipe: desempenho, perspectivas econômicas e evolução dos indicadores sociais - 1970-2004. Recife. 2005. Disponível em: <http://www.fapese.org.br/cursos/ agn_arquivos/rlacerda/ Sergipe_VFINAL.pdf >. Acesso em: 06 jun. 2014.

COSTA, José F. Reflexos da Lei de Responsabilidade Fiscal no endividamento dos municípios brasileiros. In: $18^{\circ}$ CONGRESSO BRASILEIRO DE CONTABILIDADE. 24-28 agosto 2008. Gramado/RS. Anais ... Contabilidade governamental e do terceiro setor cód. do trab. 334. Disponível em: <http://www.fucape.br/_public/producao_ cientifica/2/jose\%20fernades.pdf>. Acesso em: 09 jun. 2014.

DI BERNARDI, Rafael. B. Avaliação da Portaria MF 306/2012. Disponível em: <http://www.sefanet.pr.gov.br/dados/gefin/materiais/Analise_da_Portaria_STB_n._306_2012 Estado_do_RS.pdf $\geq$. Acesso em: 23 fev. 2015.

FUNDAÇÃO GETÚLIO VARGAS. Responsabilidade Fiscal no Brasil: uma memória da lei, FGV Projetos. 2010.

GIUBERTI, Ana Carolina. Lei de Responsabilidade Fiscal: Efeitos sobre o gasto com pessoal dos municípios brasileiros. Disponível em: <http://www.anpec.org.br/encontro2005/artigos/A05A048.pdf $\geq$. Acesso em: 04 jul. 2014.

GORONCIO, Edgar Antônio. O endividamento dos Estados brasileiros após a lei de responsabilidade fiscal (LRF). 2010. Disponível em: 
<http://www.fucape.br/_public/producao_cientifica/8/Dissertacao\%20Edgar\%20Goroncio.pdf $>$ Acesso em: 05 maio 2014.

IBGE. Contas Regionais. Participação das Grandes Regiões e Unidades da Federação no Produto Interno Bruto 2002-2012. 2014. Disponível em:

<http://www.ibge.gov.br/home/estatistica/economia/contasregionais/2012/default_ods_2002_ 2012.shtm> Consulta em 01 jun 2014.

JAYME JR, Frederico; REIS, Júlio César; ROMERO, João. Restrição orçamentária e lei de responsabilidade fiscal: um estudo para Minas Gerais (1995-2005). Texto para discussão n. ${ }^{\circ}$ 298. Belo Horizonte: UFMG/Cedeplar, 2006.

MALHOTRA, Naresh. Pesquisa de marketing: uma orientação aplicada. Trad. Nivaldo Montingelli Jr. e Alfredo Alves de Farias. 3. ed. Porto Alegre: Bookman, 2001.

MELO, Ricardo O. L. Economia Sergipana Contemporânea (1970-2002). Aracaju: Editora Diário Oficial, 2012.

MENDES, Roger da Fonseca. Gestão Fiscal e crescimento econômico: o caso dos governos estaduais do nordeste a partir da vigência da Lei de Responsabilidade Fiscal. 2009.

Disponível em: <http://www.repositorio.ufc.br/handle/riufc/5736> Acesso em: 04 jul. 2014.

NASCIMENTO, Eugênio. Albano Franco - Venda da Energipe afastou intervenção federal em Sergipe. Entrevista de 17 abr. 2011. Jornal da Cidade. 2011. Disponível em: $<$ http://www.primeiramao.blog.br/post.aspx?id=1174\&t=albano-franco---venda-da-energipeafastou-intervencao-federal-em-sergipe> Acesso em: 06 jun. 2014.

SERGIPE. Secretaria de Estado da Fazenda (SEFAZ). Balanço Geral do Governo do Estado de Sergipe. Aracaju. 1989. Consulta em 30 ago. 2014. Impresso.

SERGIPE. Secretaria de Estado da Fazenda (SEFAZ). Balanço Geral do Governo do Estado de Sergipe. Aracaju. 1993. Consulta em 30 ago. 2014. Impresso.

SERGIPE. Secretaria de Estado da Fazenda (SEFAZ). Balanço Geral do Governo do Estado de Sergipe. Aracaju. 1997. Consulta em 30 ago. 2014. Impresso.

SERGIPE. Secretaria de Estado da Fazenda (SEFAZ). Balanço Geral do Governo do Estado de Sergipe. Aracaju. 1999. Consulta em 30 ago. 2014. Impresso.

SERGIPE. Secretaria de Estado da Fazenda (SEFAZ). Balanço Geral do Governo do Estado de Sergipe. Aracaju. 2001. Disponível em:

<http://www.sefaz.se.gov.br/internet/financas/CONTAS_ANUAIS_2001.pdf>. Acesso em: 10 maio 2014.

SERGIPE. Secretaria de Estado da Fazenda (SEFAZ). Balanço Geral do Governo do Estado de Sergipe. Aracaju. 2002. Disponível em:

<http://www.sefaz.se.gov.br/internet/financas/CONTAS_ANUAIS_2002.pdf >. Acesso em: 10 maio 2014. 
SERGIPE. Secretaria de Estado da Fazenda (SEFAZ). Balanço Geral do Governo do Estado de Sergipe. Aracaju. 2003. Disponível em:

<http://www.sefaz.se.gov.br/internet/financas/CONTAS_ANUAIS_2003.pdf>. Acesso em: 10 maio 2014.

SERGIPE. Secretaria de Estado da Fazenda (SEFAZ). Balanço Geral do Governo do Estado de Sergipe. Aracaju. 2004. Disponível em:

<http://www.sefaz.se.gov.br/internet/financas/CONTAS_ANUAIS_2004.pdf>. Acesso em: 10 maio 2014.

SERGIPE. Secretaria de Estado da Fazenda (SEFAZ). Balanço Geral do Governo do Estado de Sergipe. Aracaju. 2005. Disponível em:

<http://www.sefaz.se.gov.br/internet/financas/CONTAS_ANUAIS_2005.pdf.> Acesso em: 10 maio 2014.

SERGIPE. Secretaria de Estado da Fazenda (SEFAZ). Balanço Geral do Governo do Estado de Sergipe. Aracaju. 2006. Disponível em:

<http://www.sefaz.se.gov.br/internet/financas/CONTAS_ANUAIS_2006.pdf.> Acesso em: 10 maio 2014.

SERGIPE. Secretaria de Estado da Fazenda (SEFAZ). Balanço Geral do Governo do Estado de Sergipe. Aracaju. 2007. Disponível em:

<http://www.sefaz.se.gov.br/internet/financas/CONTAS_ANUAIS_2007.pdf.> Acesso em:

10 maio 2014.

SERGIPE. Secretaria de Estado da Fazenda (SEFAZ). Balanço Geral do Governo do Estado de Sergipe. Aracaju. 2008. Disponível em:

<http://www.sefaz.se.gov.br/internet/financas/CONTAS_ANUAIS_2008.pdf.> Acesso em: em 10 maio 2014.

SERGIPE. Secretaria de Estado da Fazenda (SEFAZ). Balanço Geral do Governo do Estado de Sergipe. Aracaju. 2009. Disponível em:

http://www.sefaz.se.gov.br/internet/financas/CONTAS_ANUAIS_2009.pdf. Acesso em: 10maio 2014.

SERGIPE. Secretaria de Estado da Fazenda (SEFAZ). Balanço Geral do Governo do Estado de Sergipe. Aracaju. 2010. Disponível em:

<http://www.sefaz.se.gov.br/internet/financas/CONTAS_ANUAIS_2010.pdf.> Acesso em: 10 aio 2014.

SERGIPE. Secretaria de Estado da Fazenda (SEFAZ). Balanço Geral do Governo do Estado de Sergipe. Aracaju. 2011. Disponível em:

<http://www.sefaz.se.gov.br/internet/financas/CONTAS_ANUAIS_2011.pdf.> Acesso em: 10 maio 2014.

SERGIPE. Secretaria de Estado da Fazenda (SEFAZ). Balanço Geral do Governo do Estado de Sergipe. Aracaju. 2012. Disponível em:

<http://www.sefaz.se.gov.br/internet/financas/CONTAS_ANUAIS_2012.pdf.> Acesso em: 10 maio 2014. 
SERGIPE. Secretaria de Estado da Fazenda (SEFAZ). Balanço Geral do Governo do Estado de Sergipe. Aracaju. 2013. Disponível em:

$<$ http://www.sefaz.se.gov.br/internet/financas/CONTAS_ANUAIS _2013.pdf>. Acesso em: 10 maio 2014.

SERGIPE. Secretaria de Estado da Fazenda (SEFAZ). Classificação da Capacidade de Pagamento do Estado de Sergipe 2008-2013. 2015. Disponibilizada em 23 fev. 2015.

SERGIPE. Secretaria de Estado da Fazenda (SEFAZ). Contrato n. ${ }^{\circ}$ 005/1997. Aracaju. 1997. Impresso.

SERGIPE. Secretaria de Estado da Fazenda (SEFAZ). Contrato n. ${ }^{\mathbf{2}}$ 25.840/1994. Aracaju. 1994. Impresso.

SERGIPE. Secretaria de Estado da Fazenda (SEFAZ). Contrato n. ${ }^{0}$ 282/1990. Aracaju. 1990. Impresso.

SERGIPE. Secretaria de Estado da Fazenda (SEFAZ). Relatório da 12a Revisão do Programa de Ajuste Fiscal do Estado de Sergipe 2011-2013. 2011e. Aracaju. Impresso.

SERGIPE. Secretaria de Estado da Fazenda (SEFAZ). Relatório da 13a Revisão do Programa de Ajuste Fiscal do Estado de Sergipe 2012-2014. 2012f. Aracaju. Impresso.

SERGIPE. Secretaria de Estado da Fazenda (SEFAZ). Relatório da Audiência Pública. 2001b. Aracaju. Disponível em:

<http://www.sefaz.se.gov.br/internet/financas/AUD_PUB_Jan_Dez_2001.pdf> Acesso em: 01 jun. 2014.

SERGIPE. Secretaria de Estado da Fazenda (SEFAZ). Relatório da Audiência Pública. 2002b. Aracaju. Disponível em:

<http://www.sefaz.se.gov.br/internet/financas/AUD_PUB_Jan_Dez_2002.pdf $>$ Acesso em: 01 jun. 2014.

SERGIPE. Secretaria de Estado da Fazenda (SEFAZ). Relatório da Audiência Pública. 2003b. Aracaju. Disponível em:

<http://www.sefaz.se.gov.br/internet/financas/AUD_PUB_Jan_Dez_2003.pdf > Acesso em: 01 jun. 2014.

SERGIPE. Secretaria de Estado da Fazenda (SEFAZ). Relatório da Audiência Pública. 2004b. Aracaju. Disponível em:

<http://www.sefaz.se.gov.br/internet/financas/AUD_PUB_Jan_Dez_2004.pdf> Acesso em: 01 jun. 2014.

SERGIPE. Secretaria de Estado da Fazenda (SEFAZ). Relatório da Audiência Pública. 2005b. Aracaju. Disponível em:

<http://www.sefaz.se.gov.br/internet/financas/AUD_PUB_Jan_Dez_2005.pdf > Acesso em: 01 jun. 2014.

SERGIPE. Secretaria de Estado da Fazenda (SEFAZ). Relatório da Audiência Pública. 2006b. Aracaju. Disponível em: 
<http://www.sefaz.se.gov.br/internet/financas/AUD_PUB_Jan_Dez_2006.pdf > Acesso em: 01 jun. 2014.

SERGIPE. Secretaria de Estado da Fazenda (SEFAZ). Relatório da Audiência Pública. 2007b. Aracaju. Disponível em:

<http://www.sefaz.se.gov.br/internet/financas/AUD_PUB_Jan_Dez_2007.pdf> Acesso em: 01 jun. 2014.

SERGIPE. Secretaria de Estado da Fazenda (SEFAZ). Relatório da Audiência Pública. 2008b. Aracaju. Disponível em:

<http://www.sefaz.se.gov.br/internet/financas/AUD_PUB_Jan_Dez_2008.pdf> Acesso em: 01 jun. 2014.

SERGIPE. Secretaria de Estado da Fazenda (SEFAZ). Relatório da Audiência Pública. 2009b. Aracaju. Disponível em:

<http://www.sefaz.se.gov.br/internet/financas/AUD_PUB_Jan_Dez_2009.pdf> Acesso em: 01 jun. 2014.

SERGIPE. Secretaria de Estado da Fazenda (SEFAZ). Relatório da Audiência Pública. 2010b. Aracaju. Disponível em:

<http://www.sefaz.se.gov.br/internet/financas/AUD_PUB_Jan_Dez_2010.pdf> Acesso em: 01 jun. 2014.

SERGIPE. Secretaria de Estado da Fazenda (SEFAZ). Relatório de Gestão Fiscal (RGF). 2001d. Aracaju. Disponível em:

<www.sefaz.se.gov.br/internet/finanças/GESTÃO_Set_Dez_2001.pdf> Acesso em: 01 jun. 2014.

SERGIPE. Secretaria de Estado da Fazenda (SEFAZ). Relatório de Gestão Fiscal (RGF). 2002d. Aracaju. Disponível em:

<www.sefaz.se.gov.br/internet/finanças/GESTÃO_Set_Dez_2002.pdf> Acesso em: 01 jun. 2014.

SERGIPE. Secretaria de Estado da Fazenda (SEFAZ). Relatório de Gestão Fiscal (RGF). 2003d. Aracaju. Disponível em:

<www.sefaz.se.gov.br/internet/finanças/GESTÃO_Set_Dez_2003.pdf> Acesso em: 01 jun. 2014.

SERGIPE. Secretaria de Estado da Fazenda (SEFAZ). Relatório de Gestão Fiscal (RGF). 2004d. Aracaju. Disponível em:

<www.sefaz.se.gov.br/internet/finanças/GESTÃO_Set_Dez_2004.pdf> Acesso em: 01 jun. 2014.

SERGIPE. Secretaria de Estado da Fazenda (SEFAZ). Relatório de Gestão Fiscal (RGF). 2005d. Aracaju. Disponível em:

<www.sefaz.se.gov.br/internet/finanças/GESTÃO_Set_Dez_2005.pdf> Acesso em: 01 jun. 2014.

SERGIPE. Secretaria de Estado da Fazenda (SEFAZ). Relatório de Gestão Fiscal (RGF). 2006d. Aracaju. Disponível em: 
<www.sefaz.se.gov.br/internet/finanças/GESTÃO_Set_Dez_2006.pdf> Acesso em: 01 jun. 2014.

SERGIPE. Secretaria de Estado da Fazenda (SEFAZ). Relatório de Gestão Fiscal (RGF). 2007d. Aracaju. Disponível em:

<www.sefaz.se.gov.br/internet/finanças/GESTÃO_Set_Dez_2007.pdf> Acesso em: 01 jun. 2014.

SERGIPE. Secretaria de Estado da Fazenda (SEFAZ). Relatório de Gestão Fiscal (RGF). 2008d. Aracaju. Disponível em:

<www.sefaz.se.gov.br/internet/financas/GESTÃO_Set_Dez_2008.pdf> Acesso em: 01 jun. 2014.

SERGIPE. Secretaria de Estado da Fazenda (SEFAZ). Relatório de Gestão Fiscal (RGF). 2009d. Aracaju. Disponível em:

<www.sefaz.se.gov.br/internet/financas/GESTÃO_Set_Dez_2009.pdf> Acesso em: 01 jun. 2014.

SERGIPE. Secretaria de Estado da Fazenda (SEFAZ). Relatório de Gestão Fiscal (RGF). 2010d. Aracaju. Disponível em:

<www.sefaz.se.gov.br/internet/financas/GESTÃO_Set_Dez_2010.pdf> Acesso em: 01 jun. 2014.

SERGIPE. Secretaria de Estado da Fazenda (SEFAZ). Relatório de Gestão Fiscal (RGF). 2011d. Aracaju. Disponível em:

www.sefaz.se.gov.br/internet/financas/GESTÃO_Set_Dez_2011.pdf. Acesso em: 01 jun. 2014.

SERGIPE. Secretaria de Estado da Fazenda (SEFAZ). Relatório de Gestão Fiscal (RGF). 2012d. Aracaju. Disponível em:

<www.sefaz.se.gov.br/internet/financas/GESTÃO_Set_Dez_2012.pdf> Acesso em: 01 jun. 2014.

SERGIPE. Secretaria de Estado da Fazenda (SEFAZ). Relatório de Gestão Fiscal (RGF). 2013d. Aracaju. Disponível em:

<www.sefaz.se.gov.br/internet/financas/GESTÃO_Set_Dez_2013.pdf> Acesso em: 01 jun. 2014.

SERGIPE. Secretaria de Estado da Fazenda (SEFAZ). Relatório Resumido da Execução Orçamentária (RREO). 2001c. Aracaju. Disponível em:

<http://www.sefaz.se.gov.br/internet/financas/RREO_Nov_Dez_2001.pdf > Acesso em: 01 jun. 2014.

SERGIPE. Secretaria de Estado da Fazenda (SEFAZ). Relatório Resumido da Execução Orçamentária (RREO). 2002c. Aracaju. Disponível em:

<http://www.sefaz.se.gov.br/internet/financas/RREO_Nov_Dez_2002.pdf> Acesso em: 01 jun. 2014.

SERGIPE. Secretaria de Estado da Fazenda (SEFAZ). Relatório Resumido da Execução Orçamentária (RREO). 2003c. Aracaju. Disponível em: 
<http://www.sefaz.se.gov.br/internet/financas/RREO_Nov_Dez_2003.pdf> Acesso em: 01 jun. 2014.

SERGIPE. Secretaria de Estado da Fazenda (SEFAZ). Relatório Resumido da Execução Orçamentária (RREO). 2004c. Aracaju. Disponível em:

<http://www.sefaz.se.gov.br/internet/financas/RREO_Nov_Dez_2004.pdf> Acesso em: 01 jun. 2014.

SERGIPE. Secretaria de Estado da Fazenda (SEFAZ). Relatório Resumido da Execução Orçamentária (RREO). 2005c. Aracaju. Disponível em:

<http://www.sefaz.se.gov.br/internet/financas/RREO_Nov_Dez_2005.pdf> Acesso em: 01 jun. 2014.

SERGIPE. Secretaria de Estado da Fazenda (SEFAZ). Relatório Resumido da Execução Orçamentária (RREO). 2006c. Aracaju. Disponível em:

<http://www.sefaz.se.gov.br/internet/financas/RREO_Nov_Dez_2006.pdf> Acesso em: 01 jun. 2014.

SERGIPE. Secretaria de Estado da Fazenda (SEFAZ). Relatório Resumido da Execução Orçamentária (RREO). 2007c. Aracaju. Disponível em:

<http://www.sefaz.se.gov.br/internet/financas/RREO_Nov_Dez_2007.pdf> Acesso em: 01 jun. 2014.

SERGIPE. Secretaria de Estado da Fazenda (SEFAZ). Relatório Resumido da Execução Orçamentária (RREO). 2008c. Aracaju. Disponível em:

<http://www.sefaz.se.gov.br/internet/financas/RREO_Nov_Dez_2008.pdf> Acesso em: 01 jun. 2014.

SERGIPE. Secretaria de Estado da Fazenda (SEFAZ). Relatório Resumido da Execução Orçamentária (RREO). 2009c. Aracaju. Disponível em:

<http://www.sefaz.se.gov.br/internet/financas/RREO_Nov_Dez_2009.pdf> Acesso em: 01 jun. 2014.

SERGIPE. Secretaria de Estado da Fazenda (SEFAZ). Relatório Resumido da Execução Orçamentária (RREO). 2010c. Aracaju. Disponível em:

<http://www.sefaz.se.gov.br/internet/financas/RREO_Nov_Dez_2010.pdf> Acesso em: 01 jun. 2014.

SERGIPE. Secretaria de Estado da Fazenda (SEFAZ). Relatório Resumido da Execução Orçamentária (RREO). 2011c. Aracaju. Disponível em:

<http://www.sefaz.se.gov.br/internet/financas/RREO_Nov_Dez_2011.pdf> Acesso em: 01 jun. 2014.

SERGIPE. Secretaria de Estado da Fazenda (SEFAZ). Relatório Resumido da Execução Orçamentária (RREO). 2012c. Aracaju. Disponível em:

<http://www.sefaz.se.gov.br/internet/financas/RREO_Nov_Dez_2011.pdf > Acesso em: 01 jun. 2014.

SERGIPE. Secretaria de Estado da Fazenda (SEFAZ). Relatório Resumido da Execução

Orçamentária (RREO). 2013c. Aracaju. Disponível em: 
<http://www.sefaz.se.gov.br/internet/financas/RREO_Nov_Dez_2013.pdf> Acesso em: 01 jun. 2014.

SERGIPE. Secretaria de Estado do Planejamento, Orçamento e Gestão (SEPLAG). Relatório de Atividades do Governo do Estado de Sergipe. 2011. Disponível em:

<http://www.seplag.se.gov.br/index.php/planejamento/relatorio-de-atividades-dogoverno/relatorio-de-atividades-do-governo-2011>. Acesso em: 30 jun. 2014.

SERGIPE. Secretaria de Estado do Planejamento, Orçamento e Gestão (SEPLAG). Relatório de Atividades do Governo do Estado de Sergipe. 2012. Disponível em:

<http://www.seplag.se.gov.br/index.php/planejamento/relatorio-de-atividades-dogoverno/relatorio-de-atividades-do-governo-2012>. Acesso em: 30 jun. 2014.

SERGIPE. Secretaria de Estado do Planejamento, Orçamento e Gestão (SEPLAG). Relatório de Atividades do Governo do Estado de Sergipe. 2013. Disponível em:

$<$ http://www.seplag.se.gov.br/index.php/planejamento/relatorio-de-atividades-dogoverno/relatorio-de-atividades-do-governo-20123 >. Acesso em: 30 jun. 2014.

TAVARES, Martus. Vinte anos de política fiscal no Brasil: dos fundamentos do novo regime à lei de responsabilidade fiscal. Revista de Economia \& Relações Internacionais. v. 4. n. 7. Julho 2005. Disponível em:

<http://www.faap.br/revista_faap/rel_internacionais/pdf/revista_economia_07.pdf > . Acesso em: 06 jun. 2014.

TRIBUNAL DE CONTAS DO ESTADO DE SERGIPE (TCE). Processo TC 000081/2008. 28 fev. 2008. 
